ENTREPRENEURSHIP AND SUSTAINABILITY ISSUES

ISSN 2345-0282 (online) http://jssidoi.org/jesi/

2021 Volume 9 Number 1 (September)

http://doi.org/10.9770/jesi.2021.9.1(29)

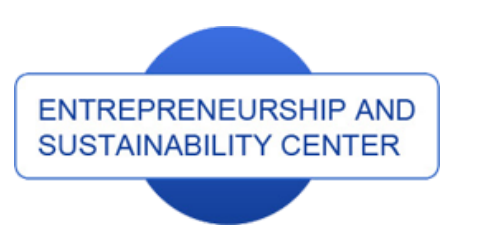

Publisher

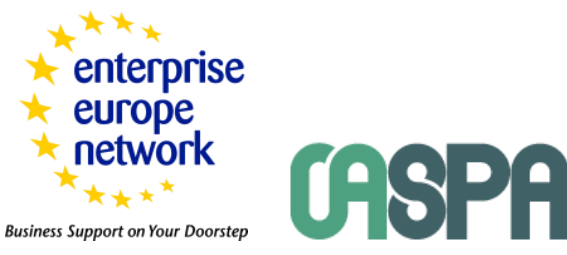

http://jssidoi.org/esc/home

Clarivate

Analytics

\title{
DIGITAL GOVERNMENT PLATFORMS: ISSUES AND ACTIONS IN EUROPE DURING PANDEMIC TIME
}

\author{
Alfonso Marino ${ }^{1}$, Paolo Pariso ${ }^{2}$ \\ ${ }^{1,2}$ Università della Campania Luigi Vanvitelli, Viale Abramo Lincoln, 5, 81100 Caserta CE, Italy \\ E-mails: ${ }^{1}$ alfonso.marino@unicampania.it; ${ }^{2}$ paolo.pariso@unicampania.it
}

Received 16 April 2021; accepted 29 July 2021; published

\begin{abstract}
The aim of the present research is to measure and assess the rise and consolidation of the digital government platforms effectiveness in the period 2016-2020 within European Union. A breakdown between countries based on their GDP expenditure share in ICT (Information and Communication Technology) is developed, in order to identify the spending propensity of the members EU 28 in the digital economy. Furthermore, with the support of the Digital Effectiveness Performance Index (DEPI). Starting from the Government Effectiveness Index (GEI), according to the five DESI dimensions, aims at identifying the sources of digital platforms effectiveness for each country. The cross national comparative study shows that in order to reduce the gap within the EU Member States, it is strategic to develop an ambitious government actions to support the remote working in terms of opportunities, challenges, drivers, processes, and consequences of the single performances, in digital dimensions, of European countries.
\end{abstract}

Keywords: Digital Effectiveness Performance Index (DEPI); effectiveness; digital platforms; cross national comparative study; European policy

Reference to this paper should be made as follows: Marino, A., Pariso, P. 2021. Digital government platforms: issues and actions in Europe during pandemic time. Entrepreneurship and Sustainability Issues, 9(1), 462-485. http://doi.org/10.9770/jesi.2021.9.1(29)

JEL Classifications: L2, L26

\section{Introduction}

The COVID-19 outbreak (Donthu et al., 2020) has upset the worldwide. The effects of the covid-19 crisis on working life (Waizenegger et al., 2020) are profound and complex. The changes in our work and social life have been rapid and full of pitfalls. The rise in unemployment and remote work has increased throughout the world. The economic and social (Keogh-Brown et al., 2010) psychological impact (Capone et al., 2020) of the pandemic has yet to be determined, but it will be significant (Marino et al., 2021). In this framework, public remote work (Skyrme, 1994; Staples et al., 1999; Scandura et al, 1997; Spreitzer et al., 2017) and digital platforms (Baiyere et al 2020; Mariani et al., 2020), impressing a smart rise in terms of both opportunities (Barsness, et al., 2005; 


\section{ENTREPRENEURSHIP AND SUSTAINABILITY ISSUES}

ISSN 2345-0282 (online) http://jssidoi.org/jesi/ 2021 Volume 9 Number 1 (September) http://doi.org/10.9770/jesi.2021.9.1(29) Carillo et al, 2020) and challenges. In order to understand possible future outcomes, it is interesting to note that digital government and market effectiveness represent key elements of the European Union's (EU) development strategy. In fact, different targets have been established in order to develop this strategy.

\section{Theoretical background}

The European Commission (2016 - 2020) has reported that a Digital Single Market with effectiveness and efficiency characteristics could contribute $€ 415$ billion per year to EU economy and allow for the creation of hundreds of thousands of new jobs. The report highlights the disparities between European countries capabilities should be considered when realizing and developing policies in the long term. Furthermore, taking European countries capacities within a set of dimensions, it could be strategic to assess the digital platforms effectiveness. As discussed by European Parliament in December 2015, reducing the digital divide may raise Gross Domestic Product (GDP) by 1-1.5\%, and in the next ten years, $90 \%$ of jobs will require relevant digital skills. Moreover, the digital divide has been substantially reduced over the last decade in Europe, but the reduction of the gap remains a strategic goal to economic development of EU countries. This is in line with the results obtained by World Bank Report (2016). Furthermore, it is interesting to note that digital divide has been declined also as geographic area (Chipeva et al., 2018) and gender (Brännström, 2012). Different authors tackled the issue of investigating the digital platforms in different contexts. A benchmarking and measurement of digital government platforms has been developed by Cattaneo et al. (2007), a survey on Italian Digital government platforms by Assinform and Confindustria (2017), as well as the issue of digital divided both in the rural areas by Kos-Łabędowicz (2017), Matuzeviciute and in developed countries, i.e. Germany (Schleife, 2010). Furthermore, Jardas et al., (2012) proposed a case study of Croatian local e-government, Butkus et al., (2017) analyzed, at international level, the relationship between the technological innovation and the unemployment, J. Wallis et al., (2018) developed a study on e-government effectiveness. For example, Kos-Łabędowicz et al. (2017) analyzed the digital divide and the factors influencing the lack of digital convergence with particular emphasis on rural areas of the European Union, where the main highlighted limit was the aging of the population and the progressive depopulation of the countryside. Moreover, Assinform and Confindustria (2017) examined the impact that the implementation of digital government may have on business, operational and service models in the different sectors of the Italian market. Instead, Wallis et al., (2018) analyzed the relationships between government effectiveness and digital government development, particularly with reference to the e-Government development (Marino et al., 2020). The study analyses such relationship utilizing five levels trust model in public context (Castaldo et al., 2010; Song et al., 2020). A model of public trust in which the importance of communication, task design and incentives for cooperation even in the presence of geographical distance, is strategic in this pandemic time (Metiu, 2006). Digital government platforms should be considered as a strategic driver for the government actions in order to improve their effectiveness. Kauffmann et al. (1999, 2010), starting from 1996, developed the methodology of the Worldwide Governance Indicators based on six composite indicators which include the Government Effectiveness Index (GEI). In this line the same authors (Kauffmann et al., 2007) highlight the strategic importance of governance indicators measure linked to digital platforms. The strategic relationship between government platforms effectiveness and digital government is reinforced by OECD (2019). OECD encourages governments to adopt strategic approaches to use technologies in order to promote more open, participatory and innovative governments. To support this aim in terms of digital government effectiveness in the European context, it is necessary to understand how the countries are organized and creating and developing more specific and effective digital platforms policies. The digital platforms are a complex matrix in which different dimensions are strictly related each other. A classification of digital platforms should consider the following dimensions: Connectivity (Olson 1983; Olson et al., 2000), Human Capital (Marino et al., 2021; Rocco, 1998), Use of Internet Service, (Lau et al., 2020; Hodgson et al., 2020). Integration of Digital Technology, (Venkatesh et al., 2000; Majchrzak et al., 2000; Nambisan et al., 2017), Digital Public Services (Cairncross, 1997; Davis et al., 1989; Davis, 1989; Allen et al., 2015). In order to measure and assess the digital platforms effectiveness, each of these dimensions is weighted and splitted in sub dimensions. The digital platforms performance combines more than 30 


\section{ENTREPRENEURSHIP AND SUSTAINABILITY ISSUES}

ISSN 2345-0282 (online) http://jssidoi.org/jesi/ 2021 Volume 9 Number 1 (September) http://doi.org/10.9770/jesi.2021.9.1(29)

indicators as indicated in Table 1. The European Commission addressed this issue by measuring the digital government platforms performance of the EU Member States through the brainchild of Digital Economy and Society Index (DESI). DESI is a composite index that summarizes relevant indicators on Europe's digital performance. It aims to help EU countries identify areas requiring priority investments and actions in order to create a truly Digital Single Market (European Commission 2017). Each dimension includes a particular aspect that contributes to the definition of a framework of the EU Member States digital platforms performance. Despite these set of indicators, DESI does not show a clear measure of digital government platforms effectiveness. This matter attracted the interest of many researchers, who tried to assess digital government platforms effectiveness. Asgarkhani (2005), has developed a study on effectiveness of e-Service in local Government, Bicking et al., (2006), proposed a scenario for e government in 2020, Arendsen, et al., (2014), analyzed the relationship between e-government and administrative burden. Bracken (2015), studied the topic of digital infrastructure through a government as platform and Janowski (2015), proposed a study on the evolution of Digital Government. Furthermore, digital transformation is changing citizens' expectations of governments, particularly in pandemic time, those linked to the ability to provide high-value, real-time digital services. Digital transformation means changing their operational methods to improve public service delivery. This process is not yet systemic (Xu et al., 2011), but should be realized short-term (Mergel et al., 2019). Following this approach, a preliminary study aimed at developing a systemic vision could be supported with semantic-based Decision Support System based on BPMN (Business Process Model Notation) that helps some of the core actors in adoption of some solutions (Pérez et al., 2004; Arpaci, 2017) in digital transformation processes (Di Martino et al., 2019). In Europe there are many bottlenecks related to digital platforms and its systemic process. In particular, Asgarkhani (2005) with a case study examined the value and the effectiveness of key aspects of digital government platforms within the public sector with a focus on four specific facets of effectiveness. Furthermore, Arendsen, et. al. (2014) analysing the scenario in Netherlands, elaborated an assessment of the business to government system. The study highlights the organizational characteristics as strategic tools to reduce the administrative burden and develop effective government policies. Janowski (2015) presents a four-stage Digital Government Evolution Model that considers pressures on government and how digital innovation is applied to address such pressures. The study analysed the high impact of Digital Government on its external environment when technological, organizational, socioeconomic (Fenner et al., 2010) and sectorial knowledge are used to ensure planning, and implementation of effective measures. On the hand, the reviewed literature shows how the digital government platforms is a driver to develop government effectiveness and how important it is to measure this effectiveness in a new digital context. Moreover, when analysing a geographic area, as the Europe, the heterogeneity of the considered countries becomes a very relevant element in function of an existing wide variability in terms of economic structure and conditions. These elements may be responsible for the gaps in terms of government platform effectiveness performances within the 28 EU Member States. A deeper analysis can be developed in order to comprehend in detail, which are the sources of the effectiveness. As shown in the elaboration of DESI (EU 2017), digital performance and competitiveness can be decomposed based on DESI dimension in order to identify measures that can be considered enhancers of platforms government effectiveness. On the other hand, in literature there is a lack of studies focusing on the effectiveness analysis of the digital government platforms and governance effectiveness at the same time, so as to allow an eventual comparison and discussion. In light of this, the present paper aims at bridging this gap introducing the Digital Effectiveness Performance Index.

In particular, digital platform government effectiveness is taken into consideration separately in the 28EU Member States for the period 2016-2020. The effectiveness analysis is based on the five DESI dimensions in order to elaborate the Digital Effectiveness Performance Index (DEPI). Moreover, a breakdown in terms of groups effectiveness for each DESI dimensions is proposed so as to establish the contribution of such dimensions to the effectiveness level of each analysed country. It is supposed that the present study will allow to support the comprehension, more in detail, on the level of the effectiveness in the field of digital platforms performance and governance in the 28 EU Member States. Furthermore, this analysis can help the quantitative identification of the contributions behind the achieved trend of platforms effectiveness and identify the countries, as best practices, to 
ENTREPRENEURSHIP AND SUSTAINABILITY ISSUES

ISSN 2345-0282 (online) http://jssidoi.org/jesi/ 2021 Volume 9 Number 1 (September) http://doi.org/10.9770/jesi.2021.9.1(29) increase the effectiveness. It is forecasted that the present analysis will be of interest for policy makers and government planners, who can acquire information for the development of government policies in long term plans. In the next sections an articulated discussion on the methodology will be developed, furthermore a deep analysis on the trend of the government effectiveness according to the digital platforms' performances in EU28 in the period 2016-2020 will be presented. Moreover, section 4 highlights the obtained results and the related discussions. Finally, section 5 shows the conclusion of the paper.

\section{Research objective and methodology}

Starting from Government Effectiveness Index (GEI) methodology, one of the six dimensions of Worldwide Governance Indicators (WGI) elaborated by Kauffmann et al., it has been developed DEPI. GEI defines the effectiveness of policy actions related to the public services. Through the analysis of several variables, the GEI contributes to the construction of the WGI. It can be considered as a synthetic benchmark of government effectiveness. The Digital Effectiveness Performance Index (DEPI), starting from the assumption of the GEI, captures the effectiveness performance of digital government strategies. It includes, as variables to analyse, the five DESI dimensions providing strategic information. DEPI derives from the theories of GEI and the digital transformation (Kehal, et al., 2003). DESI has developed an analysis linked to the relationship between two variables and their distributions share, particularly related to its five dimensions, but it does not allow to capture the effectiveness of each dimension. DEPI was formalized using the min-max method starting from the normalization of DESI 2016. The values of share and probability distributions are involved between 0 and 1 . DEPI consists on a linear projection of each indicator onto a scale between 0 and 1 (indicators with positive trend 0 min value; 1 max value). Min-Max method allows to normalize indicators in order to have an identical range [0, 1] by subtracting the minimum value and dividing by the range of the indicator values. Consequently, from the analytical point of view, the values do not diverge from each other and, therefore, the DEPI can be extended to other research fields.

Equation Min Max Method:

$$
I_{q c}^{t}=\frac{x_{q c}^{t}-\min _{c}\left(x_{q}^{t_{0}}\right)}{\max _{c}\left(x_{q}^{t_{0}}\right)-\min _{c}\left(x_{q}^{t_{0}}\right)} .
$$

The digital platforms are a complex matrix in which different dimensions have a strictly relation each other. A classification of digital platforms should consider the following dimensions. A different weight, according to their characteristics, was given to each of the five dimensions.

Table 1. Dimensions and their sub-dimensions our elaboration on DESI

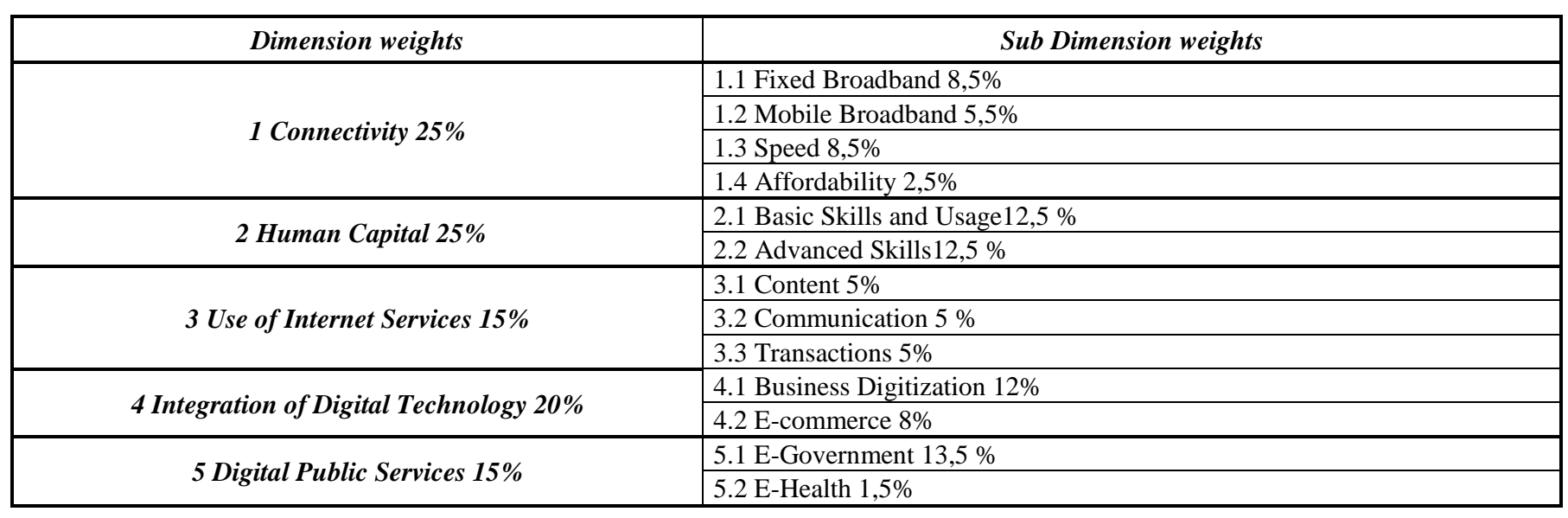




\section{ENTREPRENEURSHIP AND SUSTAINABILITY ISSUES}

ISSN 2345-0282 (online) http://jssidoi.org/jesi/ 2021 Volume 9 Number 1 (September) http://doi.org/10.9770/jesi.2021.9.1(29)

The repartition of specific weights follows these criteria:

25\% Connectivity and Human Capital. This weight, which represents the highest, has been assigned (European Commission, DESI 2018 Digital Economy and Society Index Methodological note) because it shows the countries' investments in IT (Connectivity) and Digital Economy (Human Capital).

$20 \%$ Integration of Digital Technology. This dimension captures the use of ICT by businesses.

15\% Use of Internet Services and Digital Public Services. These are the last two enabling dimensions where the first captures the use of internet by citizens and the second displays the digitization of public services.

DESI methodology does not give a clear measure of digital government platform effectiveness because it is an investment measure and does not capture how the investments improve the digital government platform effectiveness. Starting from this assumption, DEPI can be calculated in the following way:

1. $\mathrm{y}(\mathrm{w}, \mathrm{s})=\alpha(\mathrm{s})+\beta(\mathrm{s})(\mathrm{g}(\mathrm{w})+\varepsilon(\mathrm{w}, \mathrm{s}))$

\section{List of Abbreviations}

w Country, $\mathrm{w}=1,2 \ldots . \mathrm{W}$

$\mathrm{s} \quad$ Sub Dimension of DESI, $\mathrm{s}=1,2 \ldots \mathrm{S}$

$\mathrm{y}(\mathrm{w}, \mathrm{s})$ observed score on indicator s for country $\mathrm{w}$

$\mathrm{g}(\mathrm{w})$ Unobserved performance. $\mathrm{g}(\mathrm{w})$ is assumed to be in the form of a normally distributed random variable with mean 0 and standard deviation 1.

$\varepsilon(\mathrm{w}, \mathrm{s})$ Disturbance term also mentioned to as error term. It reports the perception and measurement error and variation of sample. Furthermore, it displays the imperfect relationship between the particular concept measured by indicator $\mathrm{s}$ and the corresponding broader aspect of effectiveness.

$\alpha(\mathrm{s}), \beta(\mathrm{s})$ Coefficients are useful to map, together with the disturbance term $\varepsilon(\mathrm{w}, \mathrm{s})$, unobserved governance into the observed data.

$\sigma_{\varepsilon}^{2}(\mathrm{~s})$ Variance of the disturbance terms of indicator s common to all countries $\mathrm{s}$

Digital service effectiveness is also structured by unobserved components. In order to assess these unobserved components, the effectiveness is measured by algebraically summing the scores we have obtained on each dimension $\mathrm{y}(\mathrm{w} ; \mathrm{s})$. Starting from this assumption, it is possible estimate the unknown performance $\mathrm{g}(\mathrm{w})$ but it is suitable to set jointly the error term with $\mathrm{g}(\mathrm{w})$ into brackets.

The model includes the following assumption:

1) The random terms (disturbance terms) $\varepsilon(\mathrm{w}, \mathrm{s})$, are not correlated with each other, i.e. perception errors are not correlated across dimensions and countries. In order to identify the model parameters is essential to consider that the mean of $\varepsilon(\mathrm{w}, \mathrm{s})$ is zero for all $\mathrm{w}, \mathrm{s}$.

2) The disturbance term has the same variance, $\sigma \varepsilon 2(\mathrm{w})$, among countries within a set indicator but may have a different variance among dimensions.

3) Unobserved governance and observed indicators are linearly related.

4) $\varepsilon(w, s)$ are statistically independent of $g(w)$ for all $w$ and $s$.

5) Both $\mathrm{g}(\mathrm{w})$ and $\varepsilon(\mathrm{w}, \mathrm{s})$ have a joint normal distribution.

Starting with Min Max method, MLE estimates of $\alpha(\mathrm{s}), \beta(\mathrm{s})$ and $\sigma \varepsilon(\mathrm{s})$ are achieved and this model is founded on the next Likelihood function:

$$
\text { 2. } L\left[w ; \alpha, \beta, \sigma_{\varepsilon}^{2}(1), \ldots, \sigma_{\varepsilon}^{2}(S)\right]=\prod_{w=1}^{w}(2 \cdot \pi)^{-\frac{w}{2}}|\Omega|^{-\frac{1}{2}} \exp [y(w)-\alpha] \exp [y(w)-\alpha]^{\prime} \Omega^{-1}[y(w)-\alpha]
$$

$\mathrm{S}=$ Score of dimensions

$\mathrm{W}=$ number of countries

$y(w)=$ the Sx1 vector of the $y(w, s)$ 's for country $w$

$\mathrm{y}=$ the WSx1 vector of the $\mathrm{y}(\mathrm{w}, \mathrm{s})$ 's for all countries $\alpha=\mathrm{Sx} 1$ vector of the $\alpha(\mathrm{s})$ 's

$\beta=\mathrm{Sx} 1$ vector of the $\beta(\mathrm{s})$ 's 


\section{ENTREPRENEURSHIP AND SUSTAINABILITY ISSUES}

ISSN 2345-0282 (online) http://jssidoi.org/jesi/

2021 Volume 9 Number 1 (September)

http://doi.org/10.9770/jesi.2021.9.1(29)

$\Omega=\beta \beta^{\prime}+\operatorname{diag}\{\sigma \varepsilon 2(\mathrm{~s}) \bullet \beta(\mathrm{s}) 2\}$

The formula 3 (weights $\mathrm{p}$ ) expresses a relationship in which each indicator in the aggregation procedure is inversely proportional to its error variance, i.e. the greater the variance of the error term the smaller the weight.

3. $\mathrm{p}(\mathrm{s})=\frac{\sigma_{\varepsilon}(s)^{-2}}{1+\sum_{s=1}^{s(w)} \sigma_{\varepsilon}(\mathrm{s})^{-2}}$

Considering Kaufmann et al., DEPI by equation 3 measures the performance basing itself on a weighted average of the rescaled observed scores. These rescaled scores are obtained when $\alpha(\mathrm{s})$ is subtracted from each observed score $\mathrm{y}(\mathrm{w}, \mathrm{s})$ and the result is then divided by $\beta(\mathrm{s})$. In this way it is possible rewriting equation 1 and assuming a mathematical expectation. As this is of a calculation of expected values we can hypothesize that the expected value of the disturbance term, $\varepsilon(\mathrm{w}, \mathrm{s})$, is by assumption 0 . The assumptions of equation 4 (mean) and 5 (standard deviation) imply that the conditional distribution of unobserved governance $\mathrm{g}(\mathrm{w})$ is normal.

4. $E[g(w) \mid y(w), \alpha, \beta]=\sum_{s=1}^{s(w)} p(s) \cdot \frac{y(w, s)-\alpha(s)}{\beta(s)}$

5. $\left.s d|g(w)| y(w), \sigma_{\varepsilon}^{2}(1), \ldots, \sigma_{\varepsilon}^{2}(S)\right]=\left[\sum_{s=1}^{S(w)} \sigma_{\varepsilon}^{2}(S)^{-2}\right]^{-1 / 2}$

The equation 5 wanes in the number of specific indicators in which a particular country appears and raises in the variance of the $\varepsilon(\mathrm{w}, \mathrm{s})$ on each of these indicators. In so doing, each indicator is re scaled in order that higher outcomes are equivalent to better outcomes. An additional re scaling is reached by first subtracting the minimum possible score and then dividing by the difference between the minimum and maximum possible score. The estimates of the $\alpha(\mathrm{s}), \beta(\mathrm{s})$ and $\sigma_{\varepsilon}^{2}(\mathrm{~s})$, are achieved using MLE (Eq. 2). The low level of $\sigma_{\varepsilon}^{2}(\mathrm{~s})$ means that indicators will show similar results with the other indicators. If the indicators are uncorrelated with the other indicators will have larger error variances. This correlation of scores underlies of the concept of effectiveness and not directly correlated to the perception errors. In the weight calculation, the indicators that highlight a highly correlation will express a larger weight than other indicators, because the results of equation 3 are inversely proportional to their imputed error variance. Equation 4 can now be estimated for each country so that an estimation of the level of performance $\mathrm{g}(\mathrm{w})$ is obtained. Finally, equation 5 provide the calculation of the standard error of these estimates. The estimates of effectiveness for each country are re scaled by subtracting the mean across countries and dividing by the standard deviation across countries. The scores are in the range between -2.5 and 2.5. The standard error (Equation 5) is re calculated.

\section{Data analysis}

The analysis is built up in relation with data over the period 2016-2020 recovered from Eurostat (Eurostat, 2020), which reports official statistics for EU. The first elaboration by European Commission of DESI for all the countries in EU28 is available from 2016 onward. The years before 2016 offered a reference framework with only partial data and thus not reliable for a complete analysis. However, this range is rather meaningful because many changes happened to the EU digital structure due to a set of concomitant trends. Namely speed and significant growth of IT, radical changes in digital government (de Reuver,et al., 2017), relationship between countries and economic growth (Gustova, 2017; Posvyanskaya, 2018) and the full implementation of the EU Digital government (OECD, 2014; The Digital Assembly, 2018). In the present study, firstly, the 28 EU member states are ranked on the basis of the ratio between annual GDP and ICT investments and are grouped with quartiles methodology based on DEPI scores. Table 2 reports the considered countries and the corresponding results (GDP/ICT) during the period of the analysis. This division helps to understand the possible absence of 
expenditure propension in ICT investments of the countries. Moreover, the first column of Table 2 reports a breakdown of the countries based on geographic criteria. It can be observed that geographic areas show countries with a similar structure and investments conditions. It can be observed that Table 2 shows the expenditure share of GDP in ICT, and the data highlight a progressive decrease of investment share. Malta shows the highest decrease with a negative variation with a value equal to $-1,5 \%$. The average share of investment, for the period $2016-2020$ and for all countries, is equal to 3,81\%. Considering this average value, 13 countries, out of total of 28, are above the average and 15 are under such value. Analysing the 13 countries (above the average value), it can be observed that the positive deviation from this value swings in a range with a minimum value equal to $0,13 \%$, displayed by Luxembourg, and a maximum value equal to $1,5 \%$ of the UK. Examining the other 15 countries (under the average value), the negative deviation from it swings between $-0,07$ and $-1,22$. The data highlight reflexions to do both about geographical groups and regarding the deviation from the average value of the ICT investments that will be object of subsequent analysis.

Table 2. Breakdown European Countries 2016- 2020 our elaboration from Eurostat data

\begin{tabular}{|c|c|c|c|c|c|c|c|c|c|c|c|c|c|c|c|c|c|}
\hline \multicolumn{18}{|c|}{ Breakdown European Countries 2016 - 2020} \\
\hline $\begin{array}{c}\text { Member } \\
\text { States }\end{array}$ & Groups & 2016 & GDP2016 & ICT/GDP2016 & 2017 & GDP2017 & ICT/GDP2017 & 2018 & GDP2018 & ICT/GDP2018 & 2019 & GDP2019 & ICT/GDP2019 & 2020 & GDP2020 & ICT/GDP2020 & $\begin{array}{c}\text { Average } \\
16-20\end{array}$ \\
\hline Austria (AT) & G1 & 11.126 & 329.296 & $3,38 \%$ & 11.630 & 339.896 & $3,42 \%$ & 11.610 & 350.875 & $3,31 \%$ & 11.630 & 369.899 & $3,14 \%$ & 11.638 & 388.923 & $2,99 \%$ & $3,25 \%$ \\
\hline Belgium (BE) & G1 & 13.539 & 400.643 & $3,38 \%$ & 14.016 & 409.407 & $3,42 \%$ & 14.106 & 421.607 & $3,35 \%$ & 14.045 & 439.052 & $3,20 \%$ & 14.072 & 456.497 & $3,08 \%$ & $3,29 \%$ \\
\hline $\begin{array}{c}\text { Bulgaria } \\
\text { (BG) }\end{array}$ & G4 & 2.136 & 42.751 & $5,00 \%$ & 2.155 & 44.162 & $4,88 \%$ & 2.152 & 45.708 & $4,71 \%$ & 2.219 & 51.663 & $4,29 \%$ & 2.272 & 57.618 & $3,94 \%$ & $4,56 \%$ \\
\hline Croatia (HR) & G4 & 1.886 & 43.020 & $4,38 \%$ & 2.003 & 43.897 & $4,56 \%$ & 2.018 & 44.775 & $4,51 \%$ & 2.028 & 48.990 & $4,14 \%$ & 2.059 & 53.205 & $3,87 \%$ & $4,29 \%$ \\
\hline Cyprus (CY) & G3 & $\frac{1.002}{702}$ & 17.394 & $4,04 \%$ & 734 & $\frac{43.051}{17.421}$ & $4,21 \%$ & $\frac{1.016}{744}$ & 17.543 & $4,24 \%$ & $\begin{array}{l}.020 \\
753\end{array}$ & 19.571 & $3,85 \%$ & 766 & 21.599 & $3,55 \%$ & $3,98 \%$ \\
\hline $\begin{array}{l}\text { Czech } \\
\text { Republic } \\
\text { (CZ) }\end{array}$ & G4 & 6.765 & 154.739 & $4,37 \%$ & 7.522 & 166.964 & $4.50 \%$ & 7.612 & 172.190 & $4.42 \%$ & 7.700 & 191.722 & $4.02 \%$ & 7.773 & 211.254 & $3.68 \%$ & $4.20 \%$ \\
\hline $\begin{array}{c}\text { Denmark } \\
(\mathrm{DK})\end{array}$ & G2 & 13.326 & 260.582 & $5,11 \%$ & 13.658 & 266.179 & $5,13 \%$ & 13.625 & 271.795 & $5,01 \%$ & 13.612 & 292.808 & $4,65 \%$ & 13.647 & 313.821 & $4,35 \%$ & $4,85 \%$ \\
\hline Estonia (EE) & G4 & 728 & 19.963 & $3,65 \%$ & 767 & 20.461 & $3,75 \%$ & 781 & 20.991 & $3,72 \%$ & 804 & 23.615 & $3,41 \%$ & 820 & 26.239 & $3,13 \%$ & $3,53 \%$ \\
\hline Finland (FI) & G2 & 10.296 & 205.268 & $5,02 \%$ & 10.730 & 209.149 & $5,13 \%$ & 10.724 & 212.265 & $5,05 \%$ & 10.705 & 223.892 & $4,78 \%$ & 10.760 & 235.519 & $4,57 \%$ & $4,91 \%$ \\
\hline France (FR) & G3 & 88.090 & 2.132 .449 & $4,13 \%$ & 89.103 & 2.181 .064 & $4,09 \%$ & 89.538 & 2.225 .994 & $4,02 \%$ & 89.083 & 2.291 .705 & $3,89 \%$ & 89.281 & 2.357 .416 & $3,79 \%$ & $3,98 \%$ \\
\hline $\begin{array}{c}\text { Germany } \\
\text { (DE) }\end{array}$ & G1 & 112.771 & 2.915 .650 & $3,87 \%$ & 118.174 & 3.032 .820 & $3,90 \%$ & 119.682 & 3.123 .501 & $3,83 \%$ & 119.878 & 3.386 .000 & $3,54 \%$ & 120.262 & 3.648 .499 & $3,30 \%$ & $3,69 \%$ \\
\hline Greece (EL) & G3 & 4.784 & 177.559 & $2,69 \%$ & 4.698 & 176.023 & $2,67 \%$ & 4.603 & 175.178 & $2,63 \%$ & 4.534 & 180.218 & $2,52 \%$ & 4.517 & 185.258 & $2,44 \%$ & $2,59 \%$ \\
\hline $\begin{array}{c}\text { Hungary } \\
(\mathrm{HU})\end{array}$ & G4 & 4.430 & 104.239 & $4,25 \%$ & 4.937 & 108.748 & $4,54 \%$ & 4.998 & 112.924 & $4,43 \%$ & 5.059 & 124.050 & $4,08 \%$ & 5.146 & 135.176 & $3,81 \%$ & $4,22 \%$ \\
\hline Ireland (IE) & G2 & 6.319 & 189.046 & $3,34 \%$ & 6.853 & $\begin{array}{l}10.750 \\
25.815\end{array}$ & $\frac{4,54 \%}{2,68 \%}$ & $\begin{array}{l}4.990 \\
6.959\end{array}$ & $\begin{array}{l}112.244 \\
276.434\end{array}$ & $2,52 \%$ & 6.0564 & $\begin{array}{l}1294.110 \\
\end{array}$ & $\frac{4,00 \%}{2,33 \%}$ & 6.1403 & $\begin{array}{l}13.11786 \\
31.786\end{array}$ & $\frac{2,01 \%}{2,20 \%}$ & $\frac{4,221 \%}{2,61 \%}$ \\
\hline Italy (IT) & G3 & 52.287 & 1.611 .884 & $3,24 \%$ & 53.285 & 1.636 .372 & $3,26 \%$ & 53.451 & 1.663 .863 & $3,21 \%$ & 53.706 & 1.724 .955 & $3,11 \%$ & 53.948 & 1.786 .047 & $3,02 \%$ & $3,17 \%$ \\
\hline Latvia (LV) & G4 & 713 & 23.581 & $3,02 \%$ & 773 & 24.378 & $3,17 \%$ & 798 & 25.146 & $3,18 \%$ & 809 & 27.033 & $2,99 \%$ & 819 & 28.920 & $2,83 \%$ & $3,04 \%$ \\
\hline $\begin{array}{c}\text { Lithuania } \\
\text { (LT) }\end{array}$ & G4 & 1.058 & 36.444 & $2,90 \%$ & 1.142 & 37.124 & $3,08 \%$ & 1.187 & 38.519 & $3,08 \%$ & 1.198 & 42.191 & $2,84 \%$ & 1.215 & 45.863 & $2,65 \%$ & $2.91 \%$ \\
\hline $\begin{array}{c}\text { Luxembourg } \\
(\mathrm{LU})\end{array}$ & G1 & 2.048 & 48.898 & $4,19 \%$ & 2.112 & 52.113 & $4,05 \%$ & 2.118 & 54.510 & $3,89 \%$ & 2.108 & 55.299 & $3,81 \%$ & 2.105 & 56.088 & $3,75 \%$ & $3,94 \%$ \\
\hline Malta (MT) & G3 & 351 & 8.106 & $4,33 \%$ & $\frac{2.112}{372}$ & 8.806 & $4,22 \%$ & 375 & 9.334 & $4,02 \%$ & 375 & 11.295 & $3,32 \%$ & 375 & 13.256 & $2,83 \%$ & $3,74 \%$ \\
\hline $\begin{array}{l}\text { Netherlands } \\
\text { (NL) }\end{array}$ & G1 & 31.287 & 662.770 & $4.72 \%$ & 33.249 & 676.531 & $4.91 \%$ & 33.515 & 691.009 & $4.85 \%$ & 33.548 & 772.694 & $4.34 \%$ & 33697 & 854.379 & $394 \%$ & $455 \%$ \\
\hline Poland (PL) & G4 & $\frac{31.26 /}{14.304}$ & 410.845 & $\frac{4,12 \%}{3,48 \%}$ & $\begin{array}{l}33.249 \\
15.573 \\
\end{array}$ & $\frac{0 / 6.531}{427.737}$ & $\frac{4,91 \% \%}{3,64 \%}$ & $\begin{array}{l}\frac{35.513}{15.790} \\
\end{array}$ & $\frac{691.009}{445.189}$ & $\begin{array}{l}3,85 \% \\
355 \%\end{array}$ & $\begin{array}{l}\frac{33.548}{15.968} \\
\end{array}$ & $\frac{1 / 12.094}{467.167}$ & $\frac{4,34 \%}{3,42 \%}$ & $\frac{33.697}{16.086}$ & $\frac{834.379}{489.145}$ & $\frac{3,94 \%}{3,29 \%}$ & $\frac{4,55 \%}{3,48 \%}$ \\
\hline Portugal (PT) & G3 & 7.475 & 173.446 & $4,31 \%$ & 7.522 & 179.369 & $4,19 \%$ & 7.493 & 183.620 & $4,08 \%$ & 7.428 & 194.614 & $3,82 \%$ & 7.408 & 205.608 & $3,60 \%$ & $4,00 \%$ \\
\hline Romania & G4 & 4.475 & 150230 & $298 \%$ & 4.901 & 160.353 & $306 \%$ & 5.101 & 171.207 & $298 \%$ & 5.184 & 187517 & $276 \%$ & 5.231 & 203827 & $257 \%$ & $287 \%$ \\
\hline Slovakia (SK) & G4 & 2.798 & 75.561 & $3,70 \%$ & 2.977 & 78.071 & $3,81 \%$ & 2.977 & 80.717 & $3,69 \%$ & 3.012 & $\frac{10.017}{84.851}$ & $3,55 \%$ & 3.028 & $\begin{array}{l}88.985 \\
\end{array}$ & $3,40 \%$ & $3,63 \%$ \\
\hline $\begin{array}{l}\text { Slovenia } \\
\text { (SLO) }\end{array}$ & G4 & 1.435 & 37.303 & $3,85 \%$ & 1.511 & 38.543 & $3,92 \%$ & 1.517 & 39.017 & $3,89 \%$ & 1.512 & 43.000 & $3,52 \%$ & 1.515 & 46.983 & $3,22 \%$ & $3,68 \%$ \\
\hline Spain (ES) & G3 & 40.285 & 1.041 .160 & $3,87 \%$ & 41.324 & 1.081 .190 & $3,82 \%$ & 41.343 & 1.116 .437 & $\begin{array}{l}3,89 \% \\
3,70 \% \\
\end{array}$ & $\begin{array}{l}1.012 \\
40.969\end{array}$ & $\begin{array}{l}43.060 \\
1.206 .878\end{array}$ & $\begin{array}{l}3,32 \% \\
3,39 \% \\
\end{array}$ & $\frac{1.019}{40.558}$ & $\begin{array}{l}40.983 \\
1.297 .319\end{array}$ & $\frac{3,22 \%}{3,13 \%}$ & $3,58 \%$ \\
\hline Sweden (SE) & G2 & 21.632 & 430.642 & $5,02 \%$ & 22.437 & 444.617 & $5,05 \%$ & 22.521 & 466.404 & $4,83 \%$ & 22.508 & 475.224 & $4,74 \%$ & 22.662 & 484.044 & $4,68 \%$ & $4,86 \%$ \\
\hline $\begin{array}{c}\text { United } \\
\text { Kingom } \\
\text { (UK) }\end{array}$ & G2 & 128.313 & 2.254 .297 & $5,69 \%$ & 145.685 & 2.575 .719 & $5,66 \%$ & 148.009 & 2.619 .506 & $5,65 \%$ & 147.074 & 2.930 .192 & $5,02 \%$ & 146.601 & 3.240 .878 & $4,52 \%$ & $5,31 \%$ \\
\hline
\end{tabular}

Starting from the application of DEPI methodology, Figure 1 reports Connectivity scenario. This scenario is a prerequisite for the functioning of digital platforms. The connectivity dimension takes into account both fixed and mobile broadband by considering supply and demand. Under fixed broadband, it assesses the availability as well as the take-up of basic, fast (digital natives) and ultrafast broadband. The availability of 5G and the adoption of mobile broadband are considered on mobile broadband. Digital Connectivity must be considered as a social right and network (Wellman et al.,1996), in the EU state members. A comparative assessment of Connectivity dimension displays, as reported in Fig.1, the Nordic countries (Finland and Denmark) as the strongest performers of effectiveness measured by DEPI. While the lowest scores were registered by Greece and Croatia. 
Table 3 reports the breakdown of EU 28 countries in quartiles. The first quartile (Q1) presents the lowest level of platform effectiveness, whereas belonging to the fourth quartile (Q4) show the highest platform effectiveness level based on DEPI scores on Connectivity Dimension.

Table 3. Decomposition in quartiles scores in Connectivity

\begin{tabular}{|c|c|c|c|c|c|}
\hline COUNTRIES & 2016 & 2017 & 2018 & 2019 & 2020 \\
\hline Austria & Q2 & Q2 & Q2 & Q2 & Q1 \\
\hline Belgium & Q4 & Q4 & Q4 & Q4 & Q4 \\
\hline Bulgaria & Q1 & Q1 & Q1 & Q1 & Q1 \\
\hline Croatia & Q1 & Q1 & Q1 & Q1 & Q1 \\
\hline Cyprus & Q2 & Q2 & Q2 & Q2 & Q2 \\
\hline $\begin{array}{c}\text { Czech } \\
\text { Republic }\end{array}$ & Q2 & Q1 & Q2 & Q2 & Q2 \\
\hline Denmark & Q4 & Q4 & Q4 & Q4 & Q4 \\
\hline Estonia & Q3 & Q4 & Q4 & Q4 & Q4 \\
\hline Finland & Q4 & Q4 & Q4 & Q4 & Q4 \\
\hline France & Q1 & Q2 & Q2 & Q1 & Q1 \\
\hline Germany & Q3 & Q3 & Q2 & Q3 & Q3 \\
\hline Greece & Q1 & Q1 & Q1 & Q1 & Q1 \\
\hline Hungary & Q2 & $\mathrm{Q} 2$ & Q2 & Q2 & Q2 \\
\hline Ireland & Q3 & Q3 & Q3 & Q3 & Q3 \\
\hline Italy & Q1 & Q2 & Q1 & Q1 & Q2 \\
\hline Latvia & Q3 & Q3 & Q3 & Q3 & Q3 \\
\hline Lithuania & Q3 & Q3 & Q3 & Q3 & Q3 \\
\hline Luxemburg & Q3 & Q4 & Q3 & Q3 & Q3 \\
\hline Malta & Q4 & Q3 & Q4 & Q4 & Q4 \\
\hline Netherlands & $\mathrm{Q} 4$ & Q4 & Q4 & Q4 & Q4 \\
\hline Poland & Q1 & Q1 & Q1 & Q1 & Q1 \\
\hline Portugal & Q3 & Q2 & $\mathrm{Q} 2$ & Q2 & Q3 \\
\hline Romania & Q1 & Q1 & Q1 & Q1 & Q1 \\
\hline Slovakia & Q2 & Q1 & Q1 & Q2 & Q2 \\
\hline Slovenia & Q2 & Q2 & Q3 & Q2 & Q2 \\
\hline Spain & Q2 & Q3 & Q3 & Q3 & Q2 \\
\hline Sweden & Q4 & Q4 & Q4 & Q4 & Q4 \\
\hline $\begin{array}{c}\text { United } \\
\text { Kingdom }\end{array}$ & Q4 & Q3 & Q3 & Q3 & Q3 \\
\hline
\end{tabular}

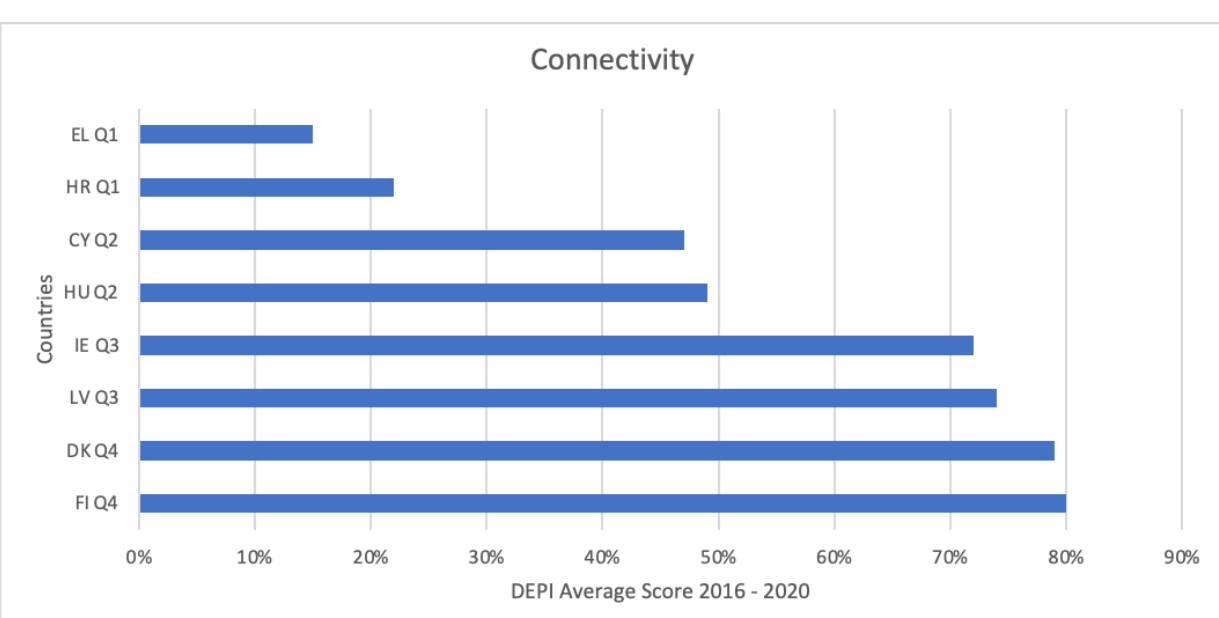

Fig. 1 DEPI Average scores 2016-2020 Connectivity

Source: Marino, Pariso on Eurostat Dataset 
Figure 2 shows the Human Capital dimension score of DEPI.

Strategic importance, in this case, is given by digital skills. Remote work should be supported by investments in both traditional and innovative educational sector.

Digital skills, i.e. the ability to use digital platforms for work, leisure and communication competently and safely. It is composed by two sub dimensions, namely "basic skills and usage" and "advanced skills and development".

Basic skills and usage sub dimension involve indicators on platform use by individuals and digital skills (basic). The other sub dimension includes indicators on ICT specialist employment and graduates in STEM - (Marino et al., 2019).

Science, Technology Engineering and Mathematics disciplines (advanced). Finland and Sweden are the top performers; instead, Romania and Bulgaria rank in the lowest overall on Human Capital dimension. Table 4 reports the breakdown of EU 28 countries in quartiles.

The first quartile (Q1) presents the lowest level of platform effectiveness, whereas the fourth quartile (Q4) shows the highest platform effectiveness level based on the DEPI scores on Human Capital Dimension. 
Table 4. Decomposition in quartiles scores in Human Capital

\begin{tabular}{|c|c|c|c|c|c|}
\hline COUNTRIES & 2016 & 2017 & 2018 & 2019 & 2020 \\
\hline Austria & Q3 & Q3 & Q3 & Q3 & Q3 \\
\hline Belgium & Q4 & Q3 & Q3 & Q3 & Q3 \\
\hline Bulgaria & Q1 & Q1 & Q1 & Q1 & Q1 \\
\hline Croatia & Q1 & Q2 & Q1 & Q1 & Q2 \\
\hline Cyprus & Q2 & Q2 & Q2 & Q2 & Q2 \\
\hline $\begin{array}{c}\text { Czech } \\
\text { Republic }\end{array}$ & Q2 & Q2 & Q2 & Q2 & Q2 \\
\hline Denmark & Q3 & Q3 & Q3 & Q3 & Q3 \\
\hline Estonia & Q3 & Q4 & Q4 & Q4 & Q4 \\
\hline Finland & Q4 & Q4 & Q4 & Q4 & Q4 \\
\hline France & Q3 & Q3 & Q3 & Q3 & Q3 \\
\hline Germany & Q3 & Q4 & Q4 & Q4 & Q4 \\
\hline Greece & Q1 & Q1 & Q1 & Q1 & Q1 \\
\hline Hungary & Q2 & Q1 & Q2 & Q2 & Q2 \\
\hline Ireland & Q4 & Q4 & Q4 & Q4 & Q4 \\
\hline Italy & Q1 & Q1 & Q1 & Q1 & Q1 \\
\hline Latvia & Q1 & $\mathrm{Q} 2$ & Q2 & Q1 & Q1 \\
\hline Lithuania & Q3 & Q3 & Q3 & Q3 & Q3 \\
\hline Luxemburg & Q4 & Q4 & Q4 & Q4 & Q4 \\
\hline Malta & Q2 & $\mathrm{Q} 2$ & Q2 & Q2 & Q1 \\
\hline Netherlands & Q4 & Q4 & Q4 & Q4 & Q4 \\
\hline Poland & Q1 & Q1 & Q1 & Q1 & Q1 \\
\hline Portugal & Q3 & Q2 & Q2 & Q2 & Q3 \\
\hline Romania & Q1 & Q1 & Q1 & Q1 & Q1 \\
\hline Slovakia & Q2 & Q1 & Q1 & Q2 & Q2 \\
\hline Slovenia & Q2 & Q3 & Q3 & Q2 & Q2 \\
\hline Spain & Q2 & Q2 & Q2 & Q2 & Q2 \\
\hline Sweden & Q4 & Q4 & Q4 & Q4 & Q4 \\
\hline $\begin{array}{c}\text { United } \\
\text { Kingdom }\end{array}$ & Q4 & Q3 & Q3 & Q3 & Q3 \\
\hline
\end{tabular}

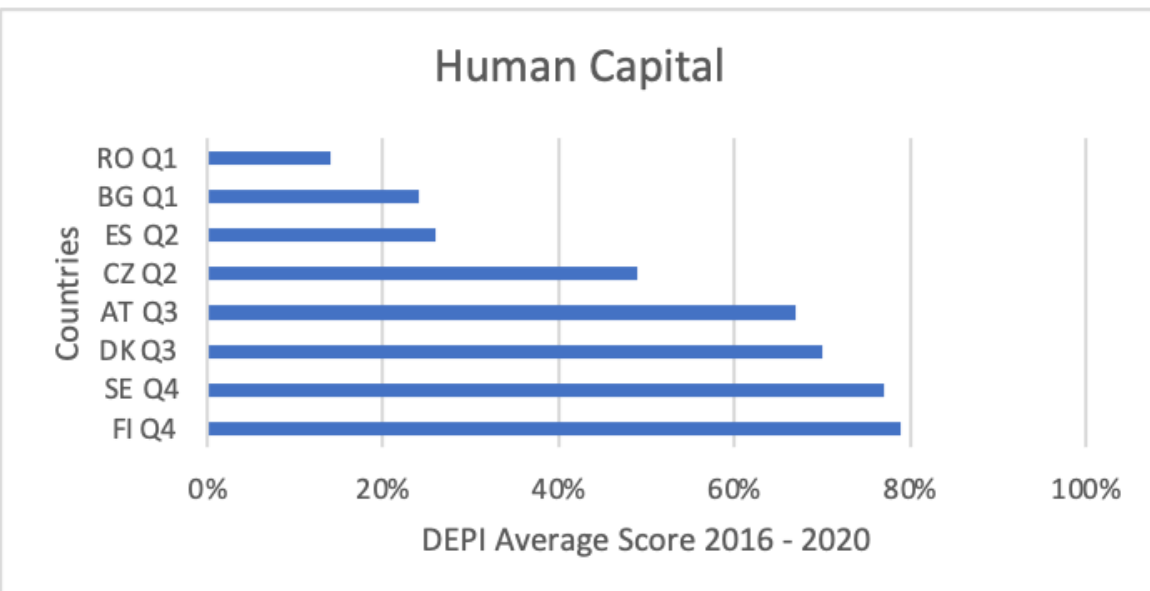

Fig. 2. DEPI Average scores 2016-2020 Human Capital

Source: Marino, Pariso on Eurostat Dataset

Source: Marino, Pariso on Eurostat Dataset 


\section{ENTREPRENEURSHIP AND SUSTAINABILITY ISSUES}

ISSN 2345-0282 (online) http://jssidoi.org/jesi/

2021 Volume 9 Number 1 (September)

http://doi.org/10.9770/jesi.2021.9.1(29)

Figure 3 displays the Use of Internet services dimension, which is made up of three sub dimensions: Citizens' use of Content, Communication and Online Transactions.

This dimension is related to digital services platforms and its services delivery, i.e., to protect personal data (Barth et al., 2017) and privacy (Acquisti et al., 2005; Acquisti et al., 2015; Awad et al., 2006). The first sub-dimensions measure the extent to which a country's platform users get online content. Furthermore, the second measures the extent to which the same users communicate and interact online via their broadband connections.

Online Transactions, instead, measures the propensity of Internet users to perform transactions online. The best performers on DEPI scores are Sweden and Denmark and the worst are again Romania (see fig. 2) and Italy. Table 5 reports the breakdown of the 28 EU countries in quartiles.

The first quartile (Q1) presents the lowest level of platform effectiveness, whereas the fourth quartile (Q4) shows the highest platform effectiveness level based on DEPI scores on Use of Internet services dimension. Figure n.4 reports Integration of Digital Technologies dimension based on the DEPI scores.

This dimension highlights the difficulty of integration between the platforms and the software that manage the information exchange relationships and the transactions between the business and government processes. It has two sub dimensions, Business digitization and e-commerce both measured by use of digital technologies.

The Business digitization sub-dimension shows the level of adoption of digital technologies by a country's businesses. The e Commerce sub-dimension measures the use of the online sales channel by a country's small and medium enterprises. Finland and once again Sweden (see fig. 2) are at the top positions of European ranking and on once again Romania (see fig. 3) and Poland occupy the last positions. 
Table 5. Decomposition in quartiles scores in Use of Internet Services

\begin{tabular}{|c|c|c|c|c|c|}
\hline COUNTRIES & 2016 & 2017 & 2018 & 2019 & 2020 \\
\hline Austria & Q2 & Q2 & $\mathrm{Q} 2$ & $\mathrm{Q} 2$ & $\mathrm{Q} 2$ \\
\hline Belgium & Q4 & Q3 & Q3 & Q3 & Q3 \\
\hline Bulgaria & Q1 & Q1 & Q1 & Q1 & Q1 \\
\hline Croatia & Q2 & Q3 & Q3 & Q2 & Q3 \\
\hline Cyprus & Q3 & Q3 & Q3 & Q3 & Q2 \\
\hline $\begin{array}{c}\text { Czech } \\
\text { Republic }\end{array}$ & $\mathrm{Q} 2$ & $\mathrm{Q} 2$ & $\mathrm{Q} 2$ & $\mathrm{Q} 2$ & Q2 \\
\hline Denmark & Q4 & Q4 & Q4 & Q4 & Q4 \\
\hline Estonia & Q3 & Q4 & Q4 & Q4 & Q4 \\
\hline Finland & Q4 & Q4 & Q4 & Q4 & Q4 \\
\hline France & Q2 & Q2 & Q2 & Q2 & Q1 \\
\hline Germany & Q3 & Q4 & Q4 & Q4 & $\mathrm{Q} 4$ \\
\hline Greece & Q1 & Q1 & Q1 & Q1 & Q1 \\
\hline Hungary & Q2 & Q1 & $\mathrm{Q} 2$ & Q2 & $\mathrm{Q} 2$ \\
\hline Ireland & Q1 & Q2 & Q2 & Q1 & Q1 \\
\hline Italy & Q1 & Q1 & Q1 & Q1 & Q1 \\
\hline Latvia & Q3 & Q3 & Q3 & Q3 & Q3 \\
\hline Lithuania & Q3 & Q3 & Q3 & Q3 & Q3 \\
\hline Luxemburg & Q4 & Q4 & Q4 & $\mathrm{Q} 4$ & Q4 \\
\hline Malta & Q3 & Q3 & Q3 & Q3 & Q3 \\
\hline Netherlands & Q4 & Q4 & Q4 & Q4 & Q4 \\
\hline Poland & Q1 & Q1 & Q1 & Q1 & Q1 \\
\hline Portugal & Q3 & Q2 & Q2 & Q2 & Q3 \\
\hline Romania & Q1 & Q1 & Q1 & Q1 & Q1 \\
\hline Slovakia & Q2 & Q1 & Q1 & Q2 & Q2 \\
\hline Slovenia & Q1 & Q3 & Q1 & Q1 & Q2 \\
\hline Spain & Q2 & $\mathrm{Q} 2$ & Q2 & Q2 & Q2 \\
\hline Sweden & Q4 & Q4 & Q4 & Q4 & Q4 \\
\hline $\begin{array}{c}\text { United } \\
\text { Kingdom }\end{array}$ & Q4 & Q3 & Q3 & Q3 & Q3 \\
\hline
\end{tabular}

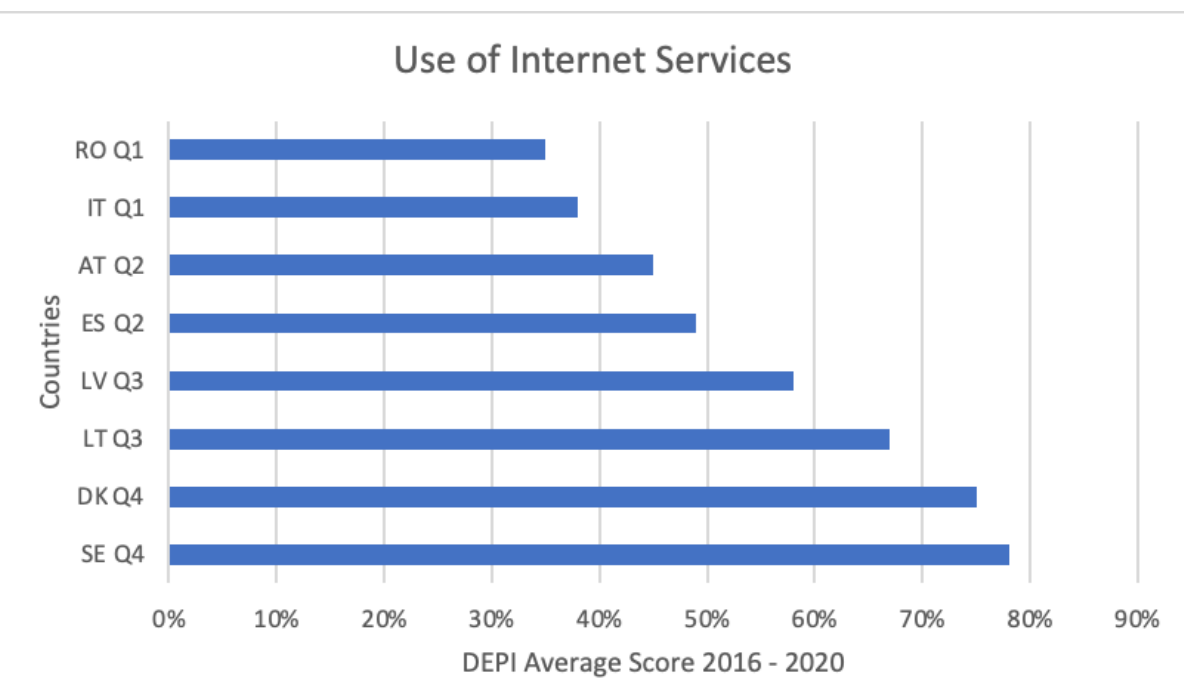

Fig. 3. DEPI Average scores 2016-2020 Use of Internet Servicesa Source: Marino, Pariso on Eurostat Dataset 
Table 6 reports the breakdown of 28 EU countries in quartiles. The first quartile (Q1) presents the lowest level of platform effectiveness, whereas the fourth quartile (Q4) shows the highest platform effectiveness level based on the DEPI scores on Digital Technologies dimension.

Table 6. Decomposition in quartiles scores in Integration of Digital Technology

\begin{tabular}{|c|c|c|c|c|c|}
\hline COUNTRIES & 2016 & 2017 & 2018 & 2019 & 2020 \\
\hline Austria & Q3 & Q2 & Q2 & Q2 & Q3 \\
\hline Belgium & Q4 & Q4 & Q4 & Q4 & Q4 \\
\hline Bulgaria & Q1 & Q1 & Q1 & Q1 & Q1 \\
\hline Croatia & Q2 & Q3 & Q3 & Q2 & Q3 \\
\hline Cyprus & Q3 & Q3 & Q3 & Q3 & Q2 \\
\hline Czech Republic & Q1 & Q2 & Q2 & Q2 & Q2 \\
\hline Denmark & Q4 & Q4 & Q4 & Q4 & Q4 \\
\hline Estonia & Q2 & Q2 & Q2 & Q2 & Q2 \\
\hline Finland & Q4 & Q4 & Q4 & Q4 & Q4 \\
\hline France & Q2 & Q2 & Q2 & Q2 & Q2 \\
\hline Germany & Q3 & Q3 & Q3 & Q3 & Q3 \\
\hline Greece & Q1 & Q1 & Q1 & Q1 & Q1 \\
\hline Hungary & Q1 & Q1 & Q1 & Q1 & Q1 \\
\hline Ireland & Q4 & Q4 & Q4 & $\mathrm{Q} 4$ & Q4 \\
\hline Italy & Q2 & Q1 & Q2 & $\mathrm{Q} 2$ & $\mathrm{Q} 2$ \\
\hline Latvia & Q1 & Q3 & Q1 & Q1 & Q2 \\
\hline Lithuania & Q3 & Q3 & Q3 & Q3 & Q3 \\
\hline Luxemburg & Q2 & Q2 & $\mathrm{Q} 2$ & Q1 & Q1 \\
\hline Malta & Q2 & Q2 & Q2 & $\mathrm{Q} 2$ & $\mathrm{Q} 2$ \\
\hline Netherlands & Q4 & Q4 & Q4 & Q4 & Q4 \\
\hline Poland & Q1 & Q1 & Q1 & Q1 & Q1 \\
\hline Portugal & Q3 & Q3 & Q3 & Q3 & Q3 \\
\hline Romania & Q1 & Q1 & Q1 & Q1 & Q1 \\
\hline Slovakia & Q2 & Q1 & Q1 & Q2 & Q1 \\
\hline Slovenia & Q3 & Q3 & Q3 & Q3 & Q3 \\
\hline Spain & Q3 & Q4 & Q4 & Q4 & Q4 \\
\hline Sweden & Q4 & Q4 & Q4 & $\mathrm{Q} 4$ & Q4 \\
\hline United Kingdom & Q4 & Q3 & Q3 & Q3 & Q3 \\
\hline
\end{tabular}

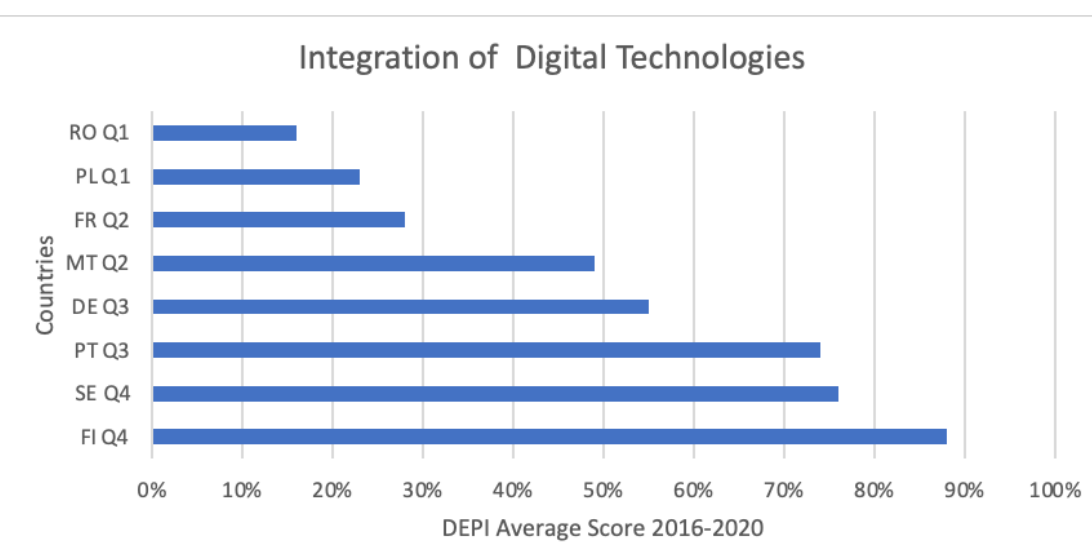

Fig. 4. DEPI Average scores 2016-2020 Integration of Digital Technology Source: Marino, Pariso on Eurostat Dataset

Figure 5 shows the effectiveness of digital public services dimension by DEPI. The digital public services dimension consists of two sub dimensions: the e Government and e Health. E - goverment platforms measures the extent of interaction, through digital services delivery, between the public administration and its stakeholders. In line with the previous sub dimension, e Health assesses the percentage of people who used health and care 
services provided online. The DEPI score European ranking shows on the top once again Finland (see figs. 2 and 4) and the United Kingdom and at the bottom, once again, Greece (see fig.1) and Hungary. Table 7 reports the breakdown of the $28 \mathrm{EU}$ countries in quartiles. The first quartile $(\mathrm{Q} 1)$ presents the lowest level of platform effectiveness, whereas the fourth quartile (Q4) shows the highest platform effectiveness level based on the DEPI scores on digital public services dimension.

Table 7. Decomposition in quartiles scores in Digital public services

\begin{tabular}{|c|c|c|c|c|c|}
\hline COUNTRIES & 2016 & 2017 & 2018 & 2019 & 2020 \\
\hline Austria & Q4 & Q4 & Q4 & Q4 & Q4 \\
\hline Belgium & Q2 & Q2 & Q2 & Q2 & Q2 \\
\hline Bulgaria & Q1 & Q1 & Q2 & Q2 & Q1 \\
\hline Croatia & Q2 & Q2 & Q1 & Q1 & Q2 \\
\hline Cyprus & Q3 & Q3 & Q3 & Q2 & Q3 \\
\hline Czech Republic & Q1 & Q2 & Q2 & Q1 & Q1 \\
\hline Denmark & Q4 & Q4 & Q4 & Q4 & Q4 \\
\hline Estonia & Q4 & Q4 & Q4 & Q4 & Q4 \\
\hline Finland & Q4 & Q4 & $\mathrm{Q} 4$ & Q4 & Q4 \\
\hline France & Q3 & Q3 & Q3 & Q3 & Q3 \\
\hline Germany & Q1 & Q3 & Q1 & Q1 & Q2 \\
\hline Greece & Q1 & Q1 & Q1 & Q1 & Q1 \\
\hline Hungary & Q1 & Q1 & Q1 & Q1 & Q1 \\
\hline Ireland & Q3 & Q3 & Q3 & Q3 & Q3 \\
\hline Italy & $\mathrm{Q} 2$ & Q1 & $\mathrm{Q} 2$ & Q2 & Q2 \\
\hline Latvia & Q3 & Q3 & Q3 & Q3 & Q3 \\
\hline Lithuania & Q3 & Q3 & Q3 & Q3 & Q3 \\
\hline Luxemburg & Q2 & Q2 & Q2 & Q2 & $\mathrm{Q} 2$ \\
\hline Malta & Q3 & Q3 & Q3 & Q3 & Q3 \\
\hline Netherlands & Q4 & Q4 & Q4 & Q4 & Q4 \\
\hline Poland & Q1 & Q1 & Q1 & Q1 & Q1 \\
\hline Portugal & Q3 & Q3 & Q3 & Q3 & Q3 \\
\hline Romania & Q1 & Q1 & Q1 & Q1 & Q1 \\
\hline Slovakia & Q2 & Q1 & Q1 & Q2 & Q1 \\
\hline Slovenia & Q2 & Q2 & Q2 & Q2 & Q2 \\
\hline Spain & Q2 & Q2 & Q2 & Q2 & Q2 \\
\hline Sweden & Q4 & Q4 & Q4 & Q4 & Q4 \\
\hline United Kingdom & Q4 & Q4 & Q4 & Q4 & Q4 \\
\hline
\end{tabular}

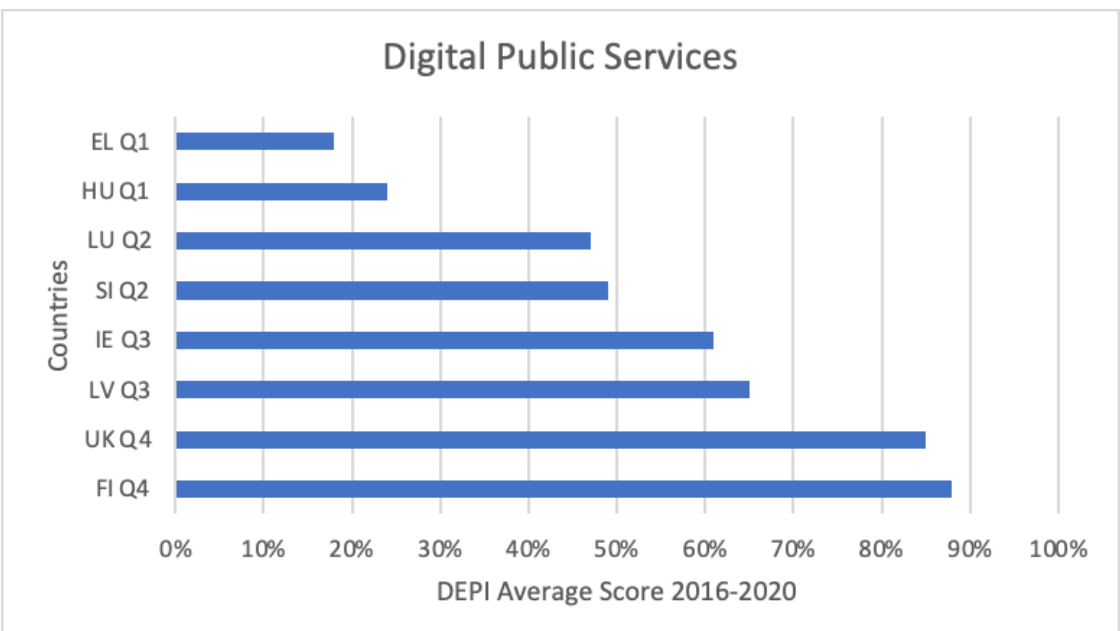

Fig. 5 DEPI Average scores 2016-2020 Digital public services

Source: Marino, Pariso on Eurostat Dataset

Source: Marino, Pariso on Eurostat Dataset 


\section{ENTREPRENEURSHIP AND SUSTAINABILITY ISSUES}

ISSN 2345-0282 (online) http://jssidoi.org/jesi/ 2021 Volume 9 Number 1 (September) http://doi.org/10.9770/jesi.2021.9.1(29)

The present data analysis confirms the peculiar situation of the 28 EU countries during the period 2016-2020 and highlights the heterogeneous conditions among the countries. Furthermore, each country displays a specific trend related to expenditure propension of the ratio of ICT/GDP and results of DEPI application in the five different DESI dimensions. At this stage some leader countries emerged by data analysis and also country profiles with deep weaknesses are shown. For these reasons, the development of a more sophisticated investigation appears appropriate.

\section{Results}

From the analysis by geographic area of the 28 EU countries, the following profiles related to ICT/GDP investment emerge. In the G4 Area (Table n.2 - Eastern Europe), except Bulgaria, Croatia and Czech Republic which show an investment share above the average value, the other 7 countries invest a lower than average amount. In these countries, a consolidation of digital platforms is needed in terms of opportunities and challenges to improve remote working (Daniels et al., 2001) and offer change processes to companies and in particular to the public sector. Particularly, for two of them, Romania and Lithuania, compared to the average value $(3,81 \%)$, the negative deviation ranges between -0,9 (RO) and - 1 (LT). Southern Europe (G3 group) offers a framework in which, out of total of 7 countries, three of these are slightly above the average value and the other four are below it. Greece, in this group, shows a negative deviation compared to the average value for a percentage equal to $1,3 \%$. In the central Europe (G1 group) Netherland e Luxembourg are slightly above the average value and the lowest score is achieved by Austria with a negative deviation compared to the average value for a percentage equal to $-1,6 \%$. Northern Europe (G2 group) ranks four, of its five countries, in the first five position, out of total of the $28 \mathrm{EU}$ Member States, in which Ireland, instead, shows a negative deviation compared to the average value for a percentage equal to $-1,2 \%$. Data analysis shows that the countries (Finland, Sweden and Denmark) with the highest share of ICT/GDP ratio investments in 2014 (year of DESI introduction) preserve their leadership until 2018 also in a general framework in which there is an overall decrease of the ICT/GDP ratio investments for the period 2014-2018. Starting with these first results, in the next sub sections a detailed discussion of DEPI dimension results will be provided. Figure 1 reports the trend of DEPI for Connectivity dimension and the sub dimensions taken into account, namely Fixed Broadband, Mobile Broadband, Speed, Affordability. Connectivity is a pre requisite to support digital platforms and its opportunity. Connectivity is a competitive investment in terms of both, development and consolidate the information and communication technology. This dimension highlight Finland is the best performer and Greece the worst. A representation among DEPI, related to Finland and Greece's connectivity sub dimensions performances, calculated by using the level values of the sub dimensions and considering their weighted parameters, is depicted respectively in Fig. 1(a) and Fig. 1(b). It can be observed that the values of these scores are different, but some common patterns can be identified. In particular, DEPI calculated on level values and weighted on the four sub dimensions of Connectivity has a similar trend related to the homogeneous European areas. Finland displays a DEPI average score for the considered period (2014-2018) equal to 1,98, and for the same period, Greece shows a total average score equal to 0,23. On the one hand, Finland achieves its best score in this dimension in the 2018 with a DEPI equal to 2,20. On the other hand also Greece obtains the best DEPI performance in Connectivity dimension with a score equal to 0,68 . Related to the connectivity sub dimensions, the strategic gap is the "affordability", in fact in Finland DEPI scored 2,01 but in Greece 0,19. This means that Greece should activate appropriate policies in order to enhance affordability in different sectors. Analyzing the results of Table n.3 it can be detected that Finland is always in Q4 and Greece always occupy Q1 position. 


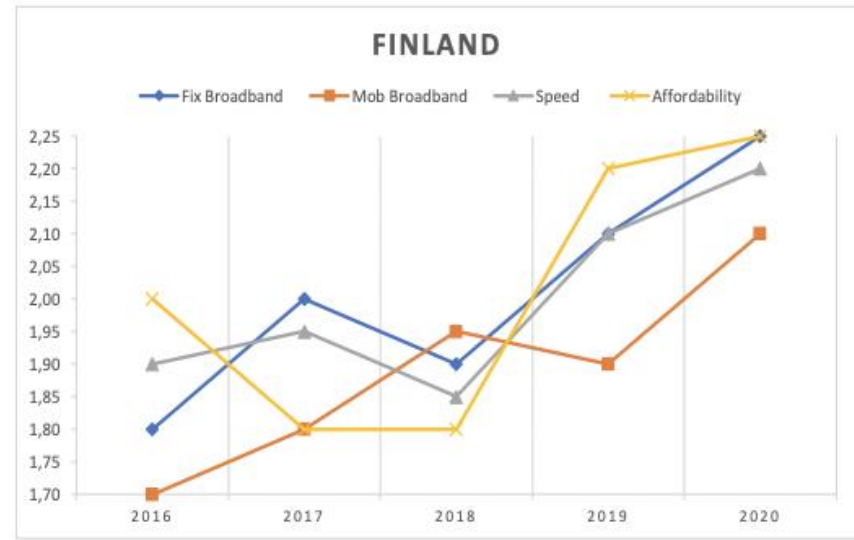

Fig. 1a Connectivity Finland

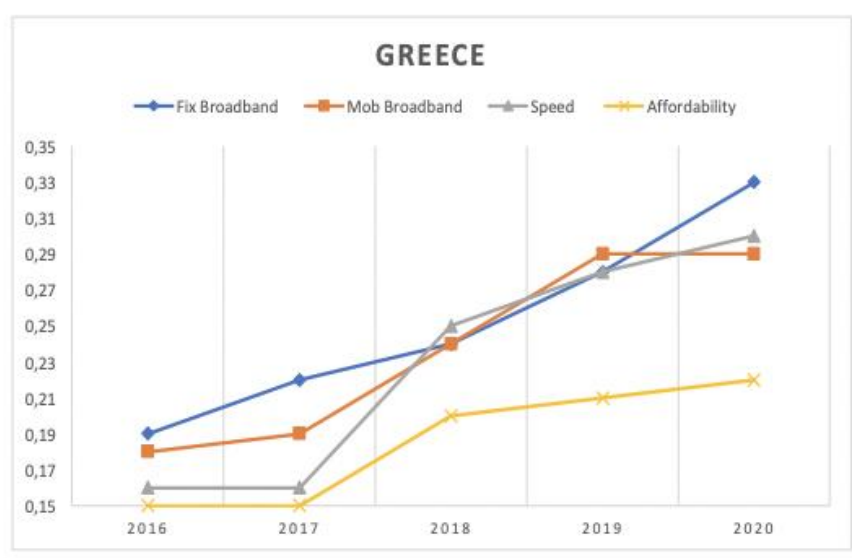

Fig. 1b Connectivity Greece

Similar considerations can be drawn when the index is referred to the Human Capital dimension. DEPI scores have different values but show a very similar trend in the Connectivity dimension. Finland (Fig. 2.a) confirms a leading position also in Human Capital with a DEPI average score for the considered period (2016-2020) equal to 1,98, and the worst performer, belonging to the Eastern European countries, is Romania (fig. 2.b) with a score equal to 0,24. Therefore, also in this case it can be said that the Human Capital dimension distribution, Basic skills and usage and Advanced skills highlight significant differences between the two countries. In the considered period, Finland displays DEPI average scores for each sub dimension equal to 1,99 (Basic) and 1,93 (Advanced). On the opposite side, the scores are 0,27 (Basic) and 0,22 (Advanced) for Romania.

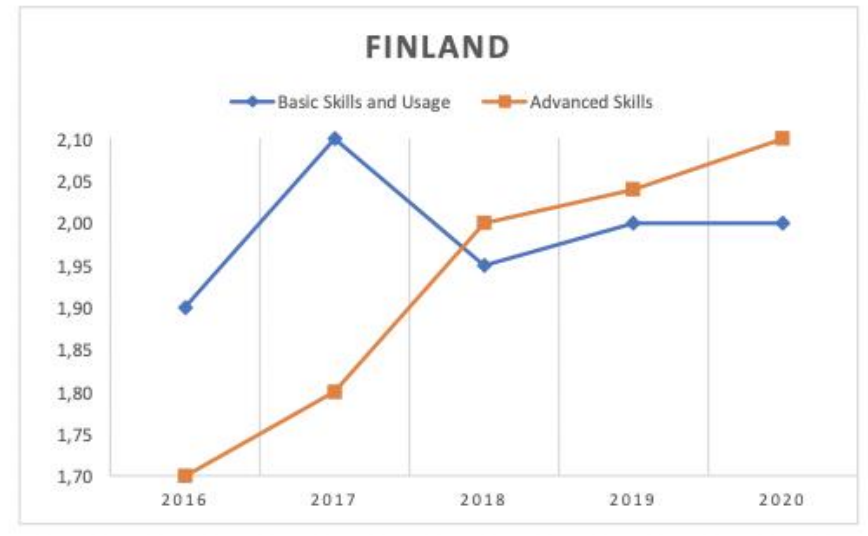

Fig. 2a Human Capital Finland

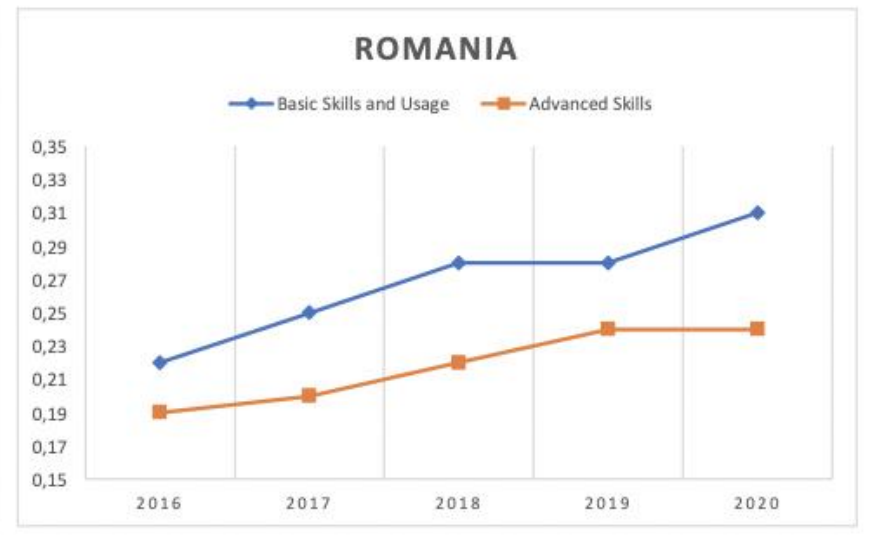

Fig. 2b Human Capital Romania

The DEPI scores calculated on the basis of the Use of Internet Services dimension follow the previous trends whereas the first two positions as held by the northern European group by contrast, there are two countries belonging to the eastern and southern European group, as shown also in Connectivity dimension. In this case the last positions are occupied by Italy and Romania, the first two, instead, by Sweden and Denmark. Those based on the GDP have different values, but the same trends. Sweden's DEPI average score (Fig. 3.a) in this dimension, for the considered period (2016-2020), is equal to 2,04, and Romania's (Fig. 3b) 0,15. Related to the Use of Internet Services sub dimension, the strategic gap is the "transaction", in which Sweden achieves a DEPI average score, for the 5 years, equal to 2,09 and Romania equal to 0,15 . It could be mean that in these two countries deep differences in terms of culture in the use of digital technologies for daily transaction by citizens are present, and in this way the first step should be to act towards a reduction of digital divide. This is in line with the general framework in this dimension displays Sweden and Denmark achieve scores linked to Q4, and Italy and Romania always occupy Q1 positions. Furthermore, in relation to the Use of Internet Services sub dimensions, Sweden has 
ENTREPRENEURSHIP AND SUSTAINABILITY ISSUES

ISSN 2345-0282 (online) http://jssidoi.org/jesi/

2021 Volume 9 Number 1 (September)

http://doi.org/10.9770/jesi.2021.9.1(29)

the best average scores in "Content" $(2,03)$ and "Transaction" $(2,09)$, instead Romania reaches its best score in "Communication" $(0,23)$.

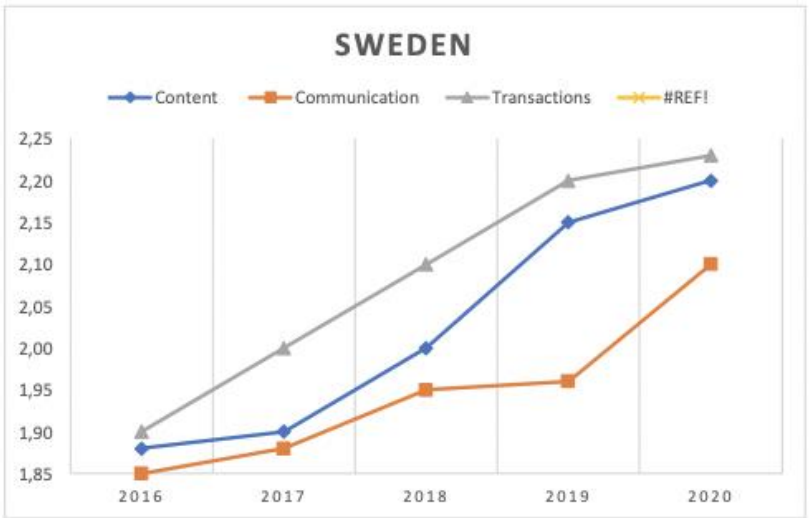

Fig. 3a Use of Internet Services Sweden

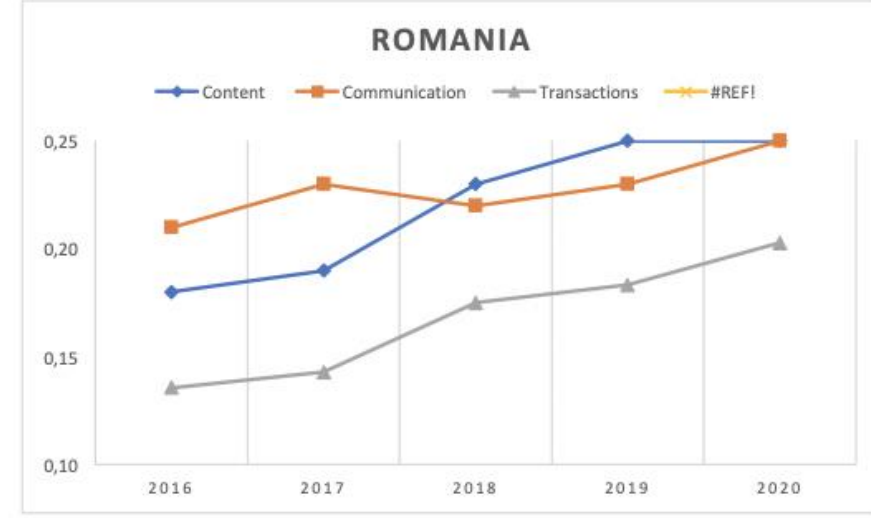

Fig. 3b Use of Internet Services Romania

Figure 4.(a) reports the DEPI score index calculated on the basis of Integration of Digital Technologies dimension for Finland that maintains, also in this dimension, a leadership with a DEPI average score, for the 5 analyzed years, equal to 2,16. Romania (Fig. 4.b) shows once again a low profile of performance with an average score equal to 0,30 . The trend is confirmed by the positions occupied by these two countries in the table $n$. 6 in which Finland is for the five years in Q4 and whereas Romania always places itself in Q1. Analyzing the two sub dimensions of the Integration of Digital Technologies, it can be observed that both countries have the best score in E-commerce sub dimension (Finland 2,20; Romania 0,32).

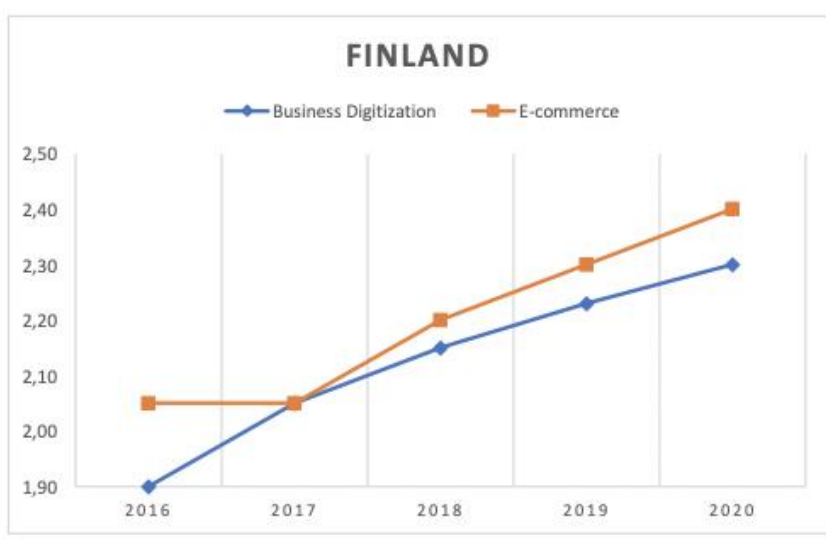

Fig. 4a Integration of Digital Technologies Finland

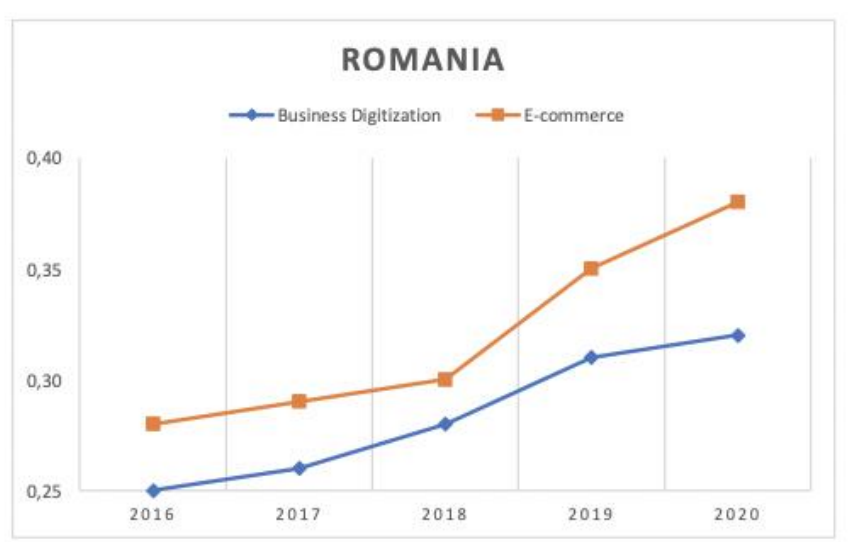

Fig. 4b Integration of Digital Technologies Romania

Figure 5 represents the trend of DEPI for Digital Public Services dimension and its two subdimensions, namely Egovernment and E-Health. As seen for the Connectivity dimension, Finland is the best performer and Greece the worst. A representation among DEPI, related to Finland and Greece's Digital Public service sub dimension performances, calculated by using the level values of the sub dimensions and considering their weighting parameters, is depicted respectively in Fig. 5(a) and Fig. 5(b). Finland obtained a DEPI average score for the analyzed period (2016-2020) of 1,91, and Greece shows a total average score equal to 0,31 . Both countries realize their best average scores in the E-government sub dimension even if the difference between the two is significant, in fact Finland's score is 1,97 and Greece's score is 0,35 . This difference, equal to 1,59 , is also present in E Health sub dimension. Table n.7 shows that Finland is always in Q4 and Greece always in Q1 position. At this level of results, a first polarization emerges in relation to the DEPI scores, in fact the first two countries belong to the Northern area (G2 group) and show a leadership in all dimensions, as shown in the graphs. The last two countries belong to the Eastern (G4 group) area and display many weaknesses. Furthermore, similar conclusions 
ENTREPRENEURSHIP AND SUSTAINABILITY ISSUES

ISSN 2345-0282 (online) http://jssidoi.org/jesi/

2021 Volume 9 Number 1 (September)

http://doi.org/10.9770/jesi.2021.9.1(29)

can be drawn from the analysis of Tables from 3-7 and it can be observed that Finland is always in Q4, and Greece and Romania are for the entire period in Q1.

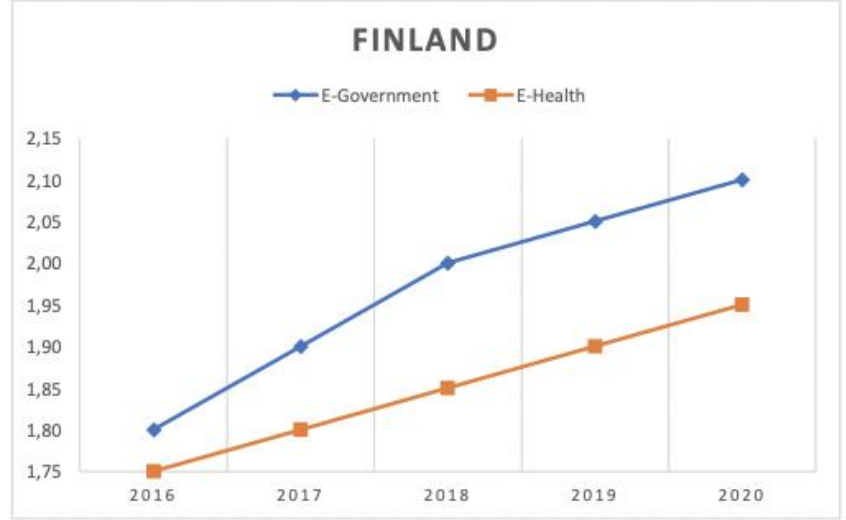

Fig. 5a Digital Public Services Finland

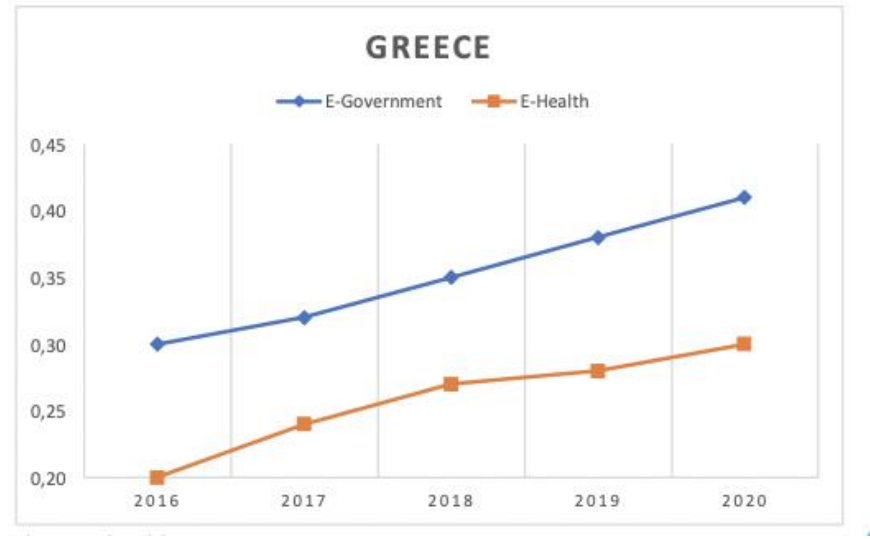

Fig. 5b Digital Public Services Greece

\section{Discussion}

By analysing the results above reported, representative countries profiles emerge in order to develop a deeply discussion. The comparisons, cross-countries allow to reveal consistent patterns and practical value. Finland, as reported in the previous graphs, shows an effectiveness leadership. Finland has been able to transform challenges into opportunities, consolidating public digital platforms, promoting remote work. The digital public platforms is managing and driving change in this pandemic phase. This leadership has been built with both planning and government actions, in fact Finland developed a Government program with goals of productivity in public services and the private sector by utilizing the digitalization as driver and reducing the red tape. Furthermore, Finland set itself the objective of delivering public services primarily in digital way. In fact, Finland displays a high level of the ICT/GDP ratio within the 28 EU Members State (see Table n.2). Furthermore, the implementation of this program started with an open letter by the government requesting proposals on how to contribute to digitalization. In twelve months, the government has received from public administration, businesses, NGOs and citizens more than 260 proposals and through the appointment of a working group some of these proposals have received funding (i.e. Income register and Virtual hospital - E-Health). This country's leadership profile is sustained, developed together with other northern European countries. It is interesting to note that this shared approach to the creation of public digital platforms, is a model that also other northern European Member States are devoting attention to consolidate and guide the relationship with citizens and stakeholders in this pandemic phase. In particular, Northern countries cooperate on their e-government effectiveness strategy and implementation. Northern European Member States are leading the digital platforms processes and highlight some good practices, such as the one described above. In fact, Denmark, Finland, Norway and Sweden share their national e-government actions and together promote both big data and open data (Ferraris et al., 2020) platforms. The big data (Wamba et al., 2015) represent a strategic step in the creation of a digital platforms service linked to consolidation of the community area. It can be observed, based on this, that the DEPI average scores show as leaders, for each dimension, these countries (G2 group). In particular, for the Connectivity dimension, the first two positions are Finland and Denmark (Fig. 1) and in the considered period, these countries always occupy Q3 or Q4 position (see Table 3). This trend is confirmed also in the other dimensions, Human Capital displays as leaders Finland and Sweden (Fig. 2) with always Q4 or Q3 position (see Table 4), Use of Internet Services shows Sweden and Denmark as the best performer (Fig. 3) and once again with a positioning for both in Q4 (see Table 5). Similarly, Integration of Digital Technology shows Finland and Sweden in the first two positions (Fig. 4) and table n. 6 always displays both countries in Q4 position. Finally, in Digital Public Services, the best performers are Finland and UK (Fig. 5) and in Table 7 it is possible to verify that both countries are always in Q4 position. On the opposite side, the most representative countries' profiles are given by Greece (G3 group) and Romania 


\section{ENTREPRENEURSHIP AND SUSTAINABILITY ISSUES}

ISSN 2345-0282 (online) http://jssidoi.org/jesi/ 2021 Volume 9 Number 1 (September) http://doi.org/10.9770/jesi.2021.9.1(29)

(G4 group), belonging respectively to the Southern and Easter European areas. The worst performances breakdown by DEPI average score assigns to Greece the last position in Connectivity and Digital Public Services and Romania the other three dimensions. Greece, as reported in the previous graphs shows, a low level of government platforms effectiveness compared to the average of the 28 EU Member States. In line with these performances Table n.2 shows, for the entire period, the lowest ICT/GDP ratio. In particular, it can be observed that this low profile is also related to weak government actions that do not emphasize the digitalization and specific planning tools for the government. Particularly, Greece has shown deficiencies in advanced digital infrastructures and interconnection of the State. In fact, Fig. 1.b highlights Greece as one of the European countries with the lowest DEPI scores in Affordability, one of the Connectivity sub dimensions. Furthermore, it could be strategic to interconnect the registers in the entire country, because it is an important element to the development of government platforms effectiveness. Moreover, Greece shows other important limits related to the modernization of the State and Public Administration and in the reconnection of the citizens with State and Public Administration. In fact, these are two strategic objectives of the Country to improve Digital Public Services. Actually, show a very below level of performance the average compared to the other Member States. These low performances are shared with other southern countries, in fact also in Italy, in the considered period the average of ICT/GDP ratio shows a significant difference with the European average share. Moreover, as to Connectivity (Table 3), together with Greece, also France, Italy and Cyprus always occupy positions between quartiles 1 and 2. Analyzing Human Capital (table 4), it can be observed that these low performances (Q1 and Q2 position) are shared by Greece, Cyprus and Italy. In the Use of Internet Services, Greece, Italy, France, and Spain are again in Q1 and Q2 positions (Table 5). This trend is confirmed in Integration of Digital Technology that shows Greece, Italy and France positioning in quartiles 1 and 2 (Table 6). Finally, in Digital Public Services once again Greece and Italy always occupy Q1 and Q2 positions (Table 7). On the basis of this, it can be concluded that in Southern European countries Greece and Italy show a lot of shared weaknesses.

Starting with the description of Greece's profile it can be assumed the Romania's performance in terms of government platforms effectiveness is very similar, in fact, also this country shows the lowest average in the ICT/GDP ratio and achieves below average effectiveness performances in each dimension. In particular, Romania occupies the last position in the DEPI average scores in relation to Human Capital, Use of Internet Services and Integration of Digital Technology dimensions. These scores are in line with the national framework. Despite many attempts to develop effectiveness government strategies, such as the creation of the National Interoperability Framework (NIF), Romania was not able to create, enforce and support policies aimed at minimising the costs and maximising the efficiency of the public administration, and at the same time to ensure a better service delivery to citizens and businesses. The Country, in fact, is not yet able to promote a public administration that uses shared ICT, reusable assets and a standardised approach to implement government platforms effectiveness. In line with the trend reported for Finland and Greece, also the performances showed by Romania are a common element with some other eastern countries. In fact, on one hand also Lithuania, Poland, Latvia, Slovakia and Slovenia, in the analyzed period, invest an average share of the ICT/GDP ratio that is below the European average share. On the other hand, also the DEPI average scores in the five dimensions express many similarities. In particular, in Connectivity dimension (Table 3), Poland, Croatia, and Bulgaria show, together with Romania, performances that rank in the first quartile and other three countries (Slovakia, Hungary and Czech Republic) are positioned in Q2. Analyzing Human Capital dimension (table 4), it can be observed that these low performances (Q1 and Q2 position) are shared also by Poland, Croatia, Bulgaria, Slovakia, Hungary, Latvia and Czech Republic. In line with these performances, also in Use of Internet Services, Integration of Digital Technology, and Digital Public Services, Bulgaria, Czech Republic, Hungary, and Slovakia performances are in line with that of Romania and positioned in quartiles 1 and 2 (Table 5, 6, 7). The reported three country profiles that reflect the trend of three different European group areas, it can be observed that the G2 area represents a country profile with a high propensity in ICT investments. This propensity is linked to actions capable of creating government effectiveness as shown by their DEPI average scores, to an inclination of taking advantage of digital government platforms, and to an ability of acquiring top positions in the long run. Despite these top positions, 


\section{ENTREPRENEURSHIP AND SUSTAINABILITY ISSUES}

ISSN 2345-0282 (online) http://jssidoi.org/jesi/ 2021 Volume 9 Number 1 (September)

http://doi.org/10.9770/jesi.2021.9.1(29)

there is a country, namely Ireland, that shows in considered period and in all dimensions, significant differences in the DEPI average scores. On the contrary, G3 and G4 areas show a countries' profiles with common regional capability deficiencies in relation with possible outcome of government platforms effectiveness. Particularly, these lacks are linked to connectivity, use of internet services and digital public services. Moreover, there is no integrated strategy between central and local public administration. The lack of these strategies also affects the educational system, particularly with relevance to digital skills training in central and local public administration. DEPI, as an assessment tool for digital government platforms effectiveness, shows that the countries in each geographic area show similar features and the imbalance within the rank is due to the differences existing among the geographic areas. The research limitations, especially in the field of choosing methodology are linked to the necessity to capture how the investments, improve the digital government platform effectiveness in relation to DESI dimensions.

\section{Conclusions}

The present paper presented a detailed analysis on the digital government platforms effectiveness of diverse country typologies within Europe. DEPI was elaborated in order to have a synthetic measure of the platform's effectiveness. It is built up by considering its five dimensions. This permitted to investigate in detail the sources of platforms effectiveness in the $28 \mathrm{EU}$ Member States, grouped in quartiles according to the level of DEPI scores. Thus, is an investigation on the relationship between effectiveness and single countries within geographical groups with respect to the digital government platforms development was developed. The analysis demonstrated a stable trend in the platforms' effectiveness, independently of the weighting dimension considered, e.g. Connectivity, Human Capital or Digital Public Services. The situation changes when the countries' profiles are investigated in relation to ICT/GDP ratio, in which a general decreasing trend is observed. This means that the countries investments share in ICT does not have similar distributions but rather a common decreasing investment trend. Analysing DEPI within the same areas the last countries' profiles do not reach different positions in the analysed period, i.e. Ireland ( $\mathrm{G} 2$ group) holds the last position, and the same consideration is also true for Greece (G3 group), that belongs to a weak European area. Therefore, it is necessary to study thus more in depth, and in the long term, because the weak countries' profiles within different European areas maintain such positions at least in the considered period. This issue is of fundamental relevance for the achievement of EU targets in terms of digital government platforms effectiveness. Similarly, it can be said that in the best performer areas, the leader countries remain such in the considered period, which implies that the different economic structure and adequate government actions of the countries play an important role in the implementation and maintenance of digital government platform development. Moreover, it can be observed that in order to support an effective European digital government policy, it is essential to work on improving, in the respect of the concrete restraints, the mix of government actions of the countries with low performances, in order to reduce both the divergences and the inequality with leader countries. In this way it is possible to reduce both gaps and lacks the worst countries and it could be simpler to set gradual European government targets. In practical terms, it is necessary to support the transition of countries belonging to Q1 and Q2 to effective government systems based on digital government platform. In particular, the effectiveness of many of these areas it is unbalanced towards some countries, in which the outflow of resources is constantly below EU28 average share of ICT/GDP ratio. The share of these investments should be consolidated by increasing the amount of effective government actions. Furthermore, digital government platform development also can help to improve a social issue, because it can ensure employment for a relevant amount of people in territories characterized by higher un-employment rates. Therefore, investments of the Europe are strategic particularly in these areas (e.g. firstly Romania and Bulgaria (G4), Greece and Italy (G3), Ireland (G2) in order to support government policies which could create new work opportunities in the digital government industry. Furthermore, the infrastructural gap should be bridged, especially in terms of Connectivity. As well, as is strategic to ensure a stable supply and to reach a stable efficient network, in order to enhance digital skills, and offer employment to the digital generation. At the same time, more investments in Digital Public Services are necessary, especially for E-government but this requires the reduction 


\section{ENTREPRENEURSHIP AND SUSTAINABILITY ISSUES}

ISSN 2345-0282 (online) http://jssidoi.org/jesi/ 2021 Volume 9 Number 1 (September) http://doi.org/10.9770/jesi.2021.9.1(29)

of digital divide, which is very wide. In conclusion, it can be said that in order to reduce the gap within the $28 \mathrm{EU}$ Member States, it is necessary to develop ambitious government actions to support the improvement of the single performances, in the digital dimensions, of European countries. This would necessitate a relevant amount of investments of the $28 \mathrm{EU}$ Member States, but would also promote a development of the government platforms effectiveness at European level. The future is not a destiny but a project, digital platform consolidation is an open question, and must be under constant development and reinterpretation.

\section{References}

Acquisti, A. Brandimarte, L. \& Loewenstein, G. (2015). Privacy and human behavior in the age of information, Science, 347(6221), 509514. https://doi.org/10.1126/science.aaa1465

Acquisti, A. and Grossklags, J. (2005). Privacy and rationality in individual decision making, IEEE security \& privacy, 3(1), 26-33. https://doi.org/10.1109/MSP.2005.22

Allen T.D., Golden T.D., \& Shockley K.M. (2015). How effective is telecommuting? Assessing the status of our scientific findings, Psychological Science in the Public Interest, 16(2), 40-68. https://doi.org/10.1177/1529100615593273

Arendsen, R., Peters, O., ter Hedde, M., \& van Dijk, J. (2014). Does e-government reduce the administrative burden of businesses? An assessment of business-to-government systems usage in the Netherlands. Government Information Quarterly, 31(1), 160-169. https://doi.org/10.1016/j.giq.2013.09.002

Arpaci, I. (2017). Antecedents and consequences of cloud computing adoption in education to achieve knowledge management. Computers in Human Behavior, 70, 382-390. https://doi.org/10.1016/j.chb.2017.01.024

Agarkhani, M. (2005). The Effectiveness of e-Service in Local Government: A Case Study. Electronic Journal of e-Government, 3(4), 157-166 https://doi.org/10.34190/EJEG.18.1.001

Assinform e Confindustria (2017). Digital Trends in Italy 2016, Rome https://www.assinform.it/In-Evidenza/Presentato-Il-RapportoAssinform-Il-Digitale-In-Italia-2017.kl (last access April 2021)

Awad, N. F., \& Krishnan, M. S. (2006). The personalization privacy paradox: an empirical evaluation of information transparency and the willingness to be profiled online for personalization. MIS quarterly, 13-28. https://doi.org/10.2307/25148715

Barsness, Z. I., Diekmann, K. A., \& Seidel, M. D. L. (2005). Motivation and opportunity: The role of remote work, demographic dissimilarity, and social network centrality in impression management. Academy of Management Journal, 48(3), 401-419. https://doi.org/10.5465/amj.2005.17407906

Barth, S., \& de Jong, M.D.T. (2017). The privacy paradox - Investigating discrepancies between expressed privacy concerns and actual online behavior - A systematic literature review. Telematics and Informatics, 34(7), 1038-1058. https://doi.org/10.1016/j.tele.2017.04.013

Baiyere, A., Salmela, H., \& Tapanainen, T. (2020). Digital transformation and the new logics of business process management. European Journal of Information Systems, 29(3), 238-259. https://doi.org/10.1080/0960085X.2020.1718007

Bicking, M., Janssen, M., \& Wimmer, M. A. (2006). Looking into the future: Scenarios for e- government in 2020. IFIP International Federation for Information Processing. https://doi.org/10.1007/978-0-387-39229-5_32

Bracken, M. (2015). Government as a Platform: the next phase of digital transformation | Government Digital Service. UK Government Digital Service. https://ec.europa.eu/jrc/sites/jrcsh/files/jrc-biap2016-united-kingdom_en.pdf

Brännström I. (2012). Gender and digital divide 2000-2008 in two low-income economies in Sub-Saharan Africa: Kenya and Somalia in official statistics. Government Information Quarterly, 29(1), 60-67. https://doi.org/10.1016/j.giq.2011.03.004

Cairncross, F. (1997). The death of distance: How the communications revolution will change our lives. Boston, MA: Harvard Business School Press.

Calisti M. (2018) The Data Economy and the next generation internet - Towards a common European data space: Internet of Things, the data economy and the Next Generation Internet, The Digital Assembly 2018

Carillo, K., Cachat-Rosset, G., Marsan, J., Saba, T., \& Klarsfeld, A. (2020). Adjusting to epidemic-induced telework: empirical insights from teleworkers in France. European Journal of Information Systems, 30(1), 69-88. https://doi.org/10.1080/0960085X.2020.1829512 Castaldo, S., Premazzi, K., \& Zerbini, F. (2010). The meaning (s) of trust. A content analysis on the diverse conceptualizations of trust in scholarly research on business relationships, Journal of business ethics, 96(4), 657-668. https://doi.org/10.1007/s10551-010-0491-4

Cattaneo G., Codagnone C., Gáspár P., Wauters P., \& Gareis K. (2007). Benchmarking and measuring digital government: lessons from the EU experience, Conference: 8th Annual International Conference on Digital Government Research, Bridging Disciplines \& Domains, DG.O 2007, Philadelphia, Pennsylvania, USA, May 20-23, 207 https://doi.org/10.1145/1248460.1248540

Capone, V., Marino, L., \& Donizzetti, A. R. (2020). The English Version of the Health Profession Communication Collective Efficacy Scale (HPCCE Scale) by Capone and Petrillo (2012). European Journal of Investigation in Health, Psychology and Education, 10(4), 10651079. https://doi.org/10.3390/ejihpe10040075

de Reuver M., Sørensen C. \& Basole R. (2017) The Digital Platform: A Research Agenda (April 2017). Journal of Information Technology, 33(2) http://dx.doi.org/10.1057/s41265-016-0033-3] 


\section{ENTREPRENEURSHIP AND SUSTAINABILITY ISSUES}

ISSN 2345-0282 (online) http://jssidoi.org/jesi/ 2021 Volume 9 Number 1 (September) http://doi.org/10.9770/jesi.2021.9.1(29)

European Commission (2017), International Digital Economy and Society Index SMART 2017/0052 Final Report) https://ec.europa.eu/digital-single-market/en/digital-economy-and-society-index-desi (last access April 2021)

Chipeva P, Cruz-Jesus F., Oliveira T. \& Irani Z. (2018). Digital divide at individual level: Evidence for Eastern and Western European countries Government Information Quarterly, 35(3), 460-479 https://doi.org/10.1016/j.giq.2018.06.003

Daniels K., Lamond D., \& Standen P. (2001). Teleworking: Frameworks for organizational research. Journal of Management Studies, 38(8), 1151-1185. https://doi.org/10.1111/1467-6486.00276

Davis, F. D. (1989). Perceived usefulness, perceived ease of use, and user acceptance of information technology. MIS quarterly, 13(3), 319-340. https://doi.org/10.2307/249008

Davis, F. D., Bagozzi, R. P. \& Warshaw, P. R. (1989). User Acceptance of Computer Technology: A Comparison of Two Theoretical Models, Management Science, 35(8), 982-1003. https://doi.org/10.1287/mnsc.35.8.982

Di Martino B., Marino A. Rak M., \& Pariso P. (2019). Optimization and Validation of eGovernment Business Processes with Support of Semantic Techniques, 13th International Conference on Complex, Intelligent, and Software Intensive Systems, CISIS 2019 Sydney; Australia, Springer publisher https://doi.org/10.1007/978-3-030-22354-0_76

Donthu, N., \& Gustafsson, A. (2020). Effects of COVID-19 on business and research. Journal of business research, 117, 284. 10.1016/j.jbusres.2020.06.008

Eurostat retrieved by http://ec.europa.eu/eurostat (Accessed 21/02/2021)

Fenner, G.H., \& Renn, R.W. (2010). Technology-assisted supplemental work and work-to-family conflict: The role of instrumentality beliefs, organizational expectations and time management, Human Relations, 63(1), 63-82. https://doi.org/10.1177/0018726709351064

Ferraris, A., Santoro, G., \& Pellicelli, A. C. (2020). "Openness" of public governments in smart cities: removing the barriers for innovation and entrepreneurship. International Entrepreneurship and Management Journal, 1-22. https://doi.org/10.1007/s11365-020-00651-4

Gustova, D. (2017) The Impact of e-Government Strategy on Economic Growth and Social Development, ISCTE Business School https://repositorio.iscte-iul.pt/bitstream/10071/15809/1/daria_gustova_diss_mestrado.pdf

Janowski, T. (2015), Digital Government Evolution: from Transformation to Contextualization, Government Information Quarterly, 32(3), 221-236. https://doi.org/10.1016/j.giq.2015.07.001

Jardas Antonić J. \& Šegota A. (2012). Measuring performance of local e-government in the republic of Croatia using data envelopment analysis. Problems and Perspectives in Management, 10(3) https://doaj.org/toc/1810-5467 Keogh-Brown, M. R., Wren-Lewis, S., Edmunds, W. J., Beutels, P., \& Smith, R. D. (2010). The possible macroeconomic impact on the UK of an influenza pandemic. Health economics, 19(11), 1345-1360. https://doi.org/10.1002/hec.1554

Kehal, H. S., \& Singh V. P (2005) Digital Economy: Impacts, Influences and Challenges, IDEA group publishing 2005

Hodgson, C., \& Wigglesworth, R. (2020). An ETF called WFH offers new way to ride remote working trend, Financial Times, 26.06.2020, https://www.ft.com/content/b99e2f22-01a2-4334-98e9-91967c0c548f

Kaufmann, D., Kraay A., \& Mastruzzi M. (2007). Response to 'What do the WorldWide Governance Indicators Measure? European Journal of Development Research, 22(1), 55-58. https://doi.org/10.1057/ejdr.2009.49

Kaufmann D., Kraay A. \& Mastruzzi M. (2009). Response to 'What do the WorldWide Governance Indicators Measure? European Journal of Development Research, 22(1), 55-58 https://doi.org/10.1057/ejdr.2009.49

Kaufmann D., Kraay A. \& Mastruzzi M. (2010) The Worldwide Governance Indicators: Methodology and Analytical Issues, Draft Policy Research Working Paper https://doi.org/10.1596/1813-9450-5430

Kaufmann D., Kraay A., \& Zoido-Lobatón P. (1999). Aggregating Governance Indicators. World Bank Policy Research Working Paper No. 2195, Washington, D.C.

Kos-Łabędowicz J. (2017), The issue of digital divide in rural areas of the European Union, Ekonomiczne Problemy Usług nr 1/2017 (126), t. 2)

Lau, J., Yang, B., \& Dasgupta, R. (2020). To Zoom or not to Zoom? That is the question, Times Higher Education. Accessed from: https://www.timeshighereducation.com/news/zoom-or-not-zoom-question on 6th of May 2020.

Mariani, M.M., \& Castaldo, S. (2020). The consolidation of Digital Platforms for Remote Working (DP4ReW) after the Covid-19 pandemic lockdown: Antecedents of Acceptance, Privacy Concerns and Implications for Users, Employers and Policy makers, working paper, Henley Business School, University of Reading.

Majchrzak A., Rice R.E., Malhotra A., King N. \& Ba S. (2000). Technology adaptation: The case of a computer-supported interorganizational virtual team, MIS Quarterly, 24(4), 569-600. https://doi.org/10.2307/3250948

Marino, A., \& Pariso, P. (2021). Human resource management in public transports: organizational typologies and research actions. VINE Journal of Information and Knowledge Management Systems. https://doi.org/10.1108/VJIKMS-01-2021-0006

Marino A., \& Pariso P. (2021). The global macroeconomic impacts of covid-19: four European scenarios. Academy of Strategic Management Journal, 20(2), 1-21.

Marino A., \& Pariso, P. (2020). From digital divide to e-government: re-engineering process and bureaucracy in public service delivery. Electronic Government, an International Journal, 16(3), 314-325. https://doi.org/10.1504/EG.2020.108495

Marino A. \& Pariso P. (2019) Stem and its impact on national economic development: a case study concerning southern Italy, 12th annual International Conference of Education, Research and Innovation - Conference Proceedings https://doi.org/10.21125/iceri.2019.0830

Matuzeviciute K., Butkus M., \& Karaliute A. (2017). Do Technological Innovations Affect Unemployment? Some Empirical Evidence from European Countries, December 2017, Economies https://doi.org/10.3390/economies5040048

Mergel, I., Edelmann, N., \& Haug, N. (2019). Defining digital transformation: Results from expert interviews. Government Information Quarterly, 36(4), 101385. https://doi.org/10.1016/j.giq.2019.06.002 


\section{ENTREPRENEURSHIP AND SUSTAINABILITY ISSUES}

ISSN 2345-0282 (online) http://jssidoi.org/jesi/ 2021 Volume 9 Number 1 (September)

http://doi.org/10.9770/jesi.2021.9.1(29)

Metiu A. (2006). Owning the code: Status closure in distributed groups, Organization Science, 17(4), 418-435. https://doi.org/10.1287/orsc.1060.0195

Nambisan, S. (2017). Digital entrepreneurship: Toward a digital technology perspective of entrepreneurship. Entrepreneurship Theory and Practice, 41(6), 1029-1055. https://doi.org/10.1111/etap.12254

OECD (2014) Recommendation of the Council on Digital Government Strategies http://www.oecd.org/gov/digitalgovernment/recommendation-on-digital-government-strategies.htm

Olson G.M., \& Olson J.S. (2000). Distance matters, Human-Computer Interaction, 139-178. https://doi.org/10.1207/S15327051HCI1523_4 Olson, M. H. (1983). Remote office work: changing work patterns in space and time. Communications of the ACM, 26(3), 182-187. https://doi.org/10.1145/358061.358068

Pérez, M.P., Sánchez, A.M., de Luis Carnicer, P., \& Jiménez, M.J. V. (2004). A technology acceptance model of innovation adoption: the case of teleworking. European Journal of innovation management, 7(4), 280-291. https://doi.org/10.1108/14601060410565038

Posvyanskaya, A. (2018) Income Inequality and Economic Growth: A Meta-Analysis, Charles University in Prague, Faculty of Social Sciences Institute of Economic Studies https://is.cuni.cz/webapps/zzp/detail/176396/?lang=en

Rocco, E. (1998). Trust breaks down in electronic contexts but can be repaired by some initial face-to-face contact. Proceedings of the CHI'98 Conference on Human Factors in Computing Systems, 496-502. New York: ACM. https://doi.org/10.1145/274644.274711

Scandura T.A., \& Lankau M.J. (1997). Relationships of gender, family responsibility and flexible work hours to organizational commitment and job satisfaction, Journal of Organizational Behavior, 18(4), 377-391. https://doi.org/10.1002/(SICI)10991379(199707)18:4<377::AID-JOB807>3.0.CO;2-1

Schleife, K. (2010). What really matters: Regional versus individual determinants of the digital divide in Germany, Research Policy 39 173-185 https://doi.org/10.1016/j.respol.2009.11.003

Skyrme D.J. (1994). Flexible working: Building a lean and responsive organization, Long Range Planning, 27(5), 98-110. https://doi.org/10.1016/0024-6301(94)90231-3

Song, C.-H., Kim, S.W., \& Sohn, Y.-W. (2020). Acceptance of public cloud storage services in South Korea: A multi-group analysis, International Journal of Information Management, 51, April, 102035. https://doi.org/10.1016/j.ijinfomgt.2019.11.003

Spreitzer, G.M., Cameron, L., \& Garrett, L. (2017). Alternative Work Arrangements: Two Images of the New World of Work. Annual Review of Organizational Psychology and Organizational Behavior, 4, 473-499. https://doi.org/10.1146/annurev-orgpsych-032516-113332 Staples, D. S., Hulland, J. S., \& Higgins, C. A. (1999). A self-efficacy theory explanation for the management of remote workers in virtual organizations. Organization Science, 10(6), 758-776. https://doi.org/10.1287/orsc.10.6.758

Venkatesh, V., \& Davis, F. D. (2000). A theoretical extension of the technology acceptance model: Four longitudinal field studies. Management Science, 46(2), 186-204. https://doi.org/10.1287/mnsc.46.2.186.11926

Waizenegger, L., McKenna, B., Cai, W., \& Bendz, T. (2020). An affordance perspective of team collaboration and enforced working from home during COVID-19. European Journal of Information Systems, 29(4), 429-442. https://doi.org/10.1080/0960085X.2020.1800417

Wallis J. \& Zhao F. (2018) e-Government Development and Government Effectiveness: A Reciprocal Relationship, International Journal of Public Administration, 41(7), 479-491. https://doi.org/10.1080/01900692.2016.1273950

Wamba, S. F., Akter, S., Edwards, A., Chopin, G., \& Gnanzou, D. (2015). How 'big data'can make big impact: Findings from a systematic review and a longitudinal case study. International Journal of Production Economics, 165, 234-246. https://doi.org/10.1016/j.ijpe.2014.12.031

Wellman B., Salaff J., Dimitrova D., Garton L., Gulia M., \& Haythorntkwaite C. (1996). Computer networks as social networks: Collaborative Work, Telework, and Virtual Community, Annual Review of Sociology, 213-238. https://doi.org/10.1146/annurev.soc.22.1.213

World Development Report 2016: https://www.worldbank.org/en/publication/wdr2016

Xu, H., Luo, X., Carroll, J.M., \& Rosson, M.B. (2011). The personalization privacy paradox: An exploratory study of decision-making process for location-aware marketing, Decision Support Systems, 51(1), 42-52. https://doi.org/10.1016/j.dss.2010.11.017

\section{Acknowledgements}

As part of the Research Program V: ALERE - Università della Campania Luigi Vanvitelli

We declare that, the work has not been published previously, that it is not under consideration for publication elsewhere, that its publication is approved by all authors and tacitly or explicitly by the responsible authorities where the work was carried out, and that, if accepted, it will not be published elsewhere in the same form, in English or in any other language, including electronically without the written consent of the copyright-holder. 
ENTREPRENEURSHIP AND SUSTAINABILITY ISSUES

ISSN 2345-0282 (online) http://jssidoi.org/jesi/

2021 Volume 9 Number 1 (September)

http://doi.org/10.9770/jesi.2021.9.1(29)

\footnotetext{
Alfonso MARINO, professor circular economy, (Università della Campania - Luigi Vanvitelli) degree in business economics with specific competencies in sustainability and circular economy.

ORCID ID: https://orcid.org/0000-0003-1722-0539
}

Paolo PARISO, PhD student in business economics, (Università della Campania - Luigi Vanvitelli) degree in business economics, with specific competences in SMEs.

ORCID ID: https://orcid.org/0000-0003-1066-4102

Make your research more visible, join the Twitter account of ENTREPRENEURSHIP AND SUSTAINABILITY ISSUES: @Entrepr69728810

Copyright (C) 2021 by author(s) and VsI Entrepreneurship and Sustainability Center

This work is licensed under the Creative Commons Attribution International License (CC BY).

http://creativecommons.org/licenses/by/4.0/

(c) (†) Open Access 